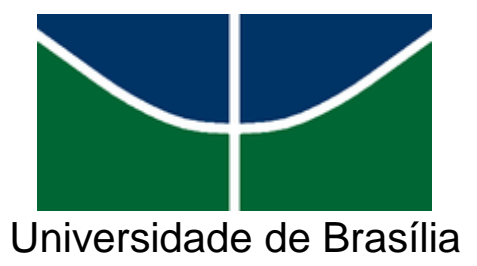

Programa de pós-graduação em Ciências da Saúde

\title{
FONKOUA MARTIN
}

\section{Efeitos de agentes desidratantes sobre fibras de cromatina e cromatossoma reconstituídos in vitro.}




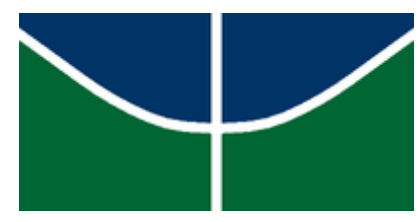

Universidade de Brasília

Programa de pós-graduação em Ciências da Saúde

\title{
FONKOUA MARTIN
}

\section{Efeitos de agentes desidratantes sobre fibras de cromatina e cromatossoma reconstituídos in vitro.}

\author{
Tese apresentada como requisito parcial \\ para obtenção do título de Doutor em \\ Ciência. da Saúde pelo Programa de Pós- \\ graduação em Ciências da Saúde da \\ Universidade de Brasília,
}

Orientador: Guilherme Martins Santos

BRASÍLIA - 2015 


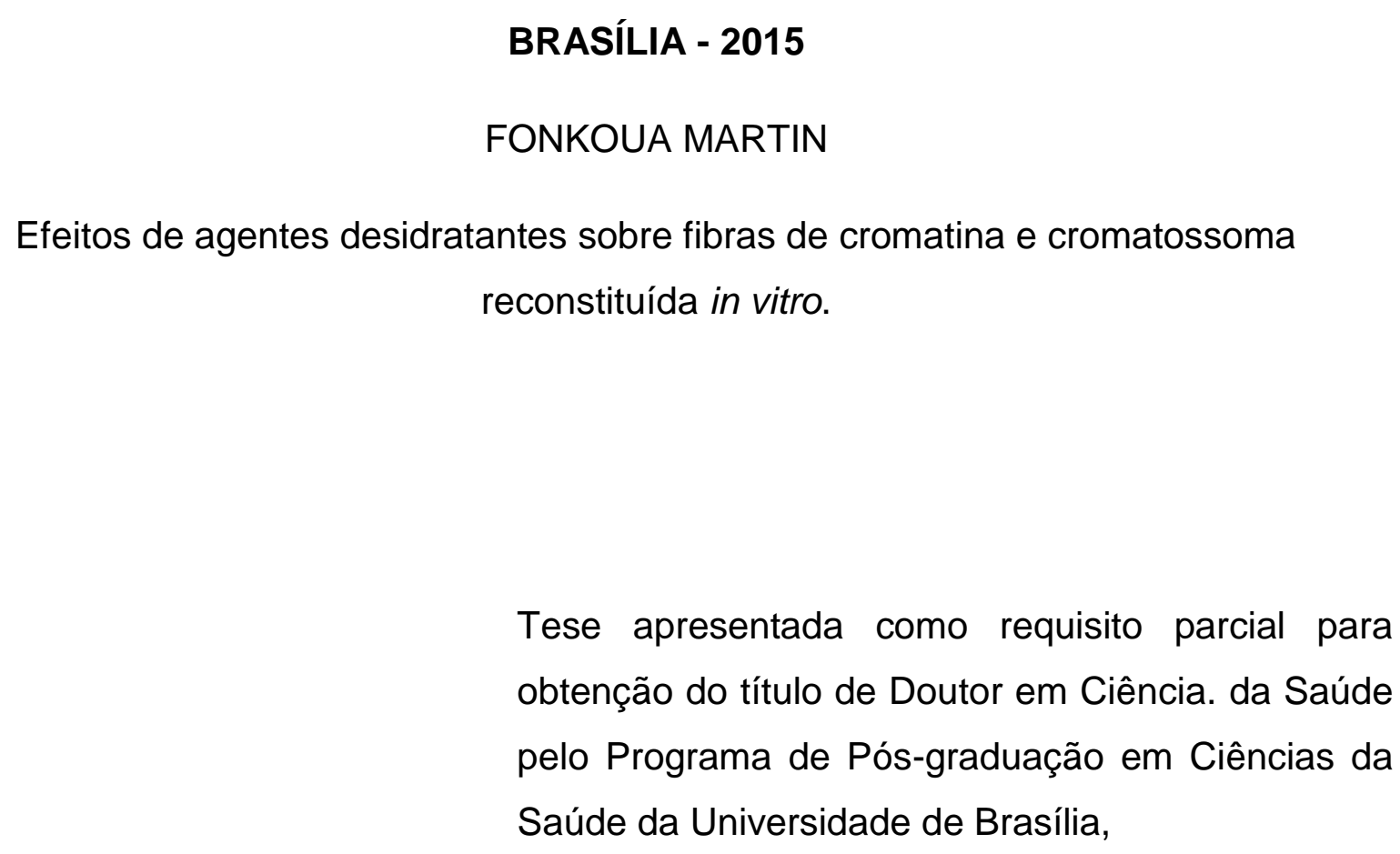

Aprovada em: 10/07/2015.

BANCA EXAMINADORA

Prof. Guilherme Martins Santos (Presidente)

(Universidade de Brasília)

Prof. Ranieri Rodrigues de Oliveira

(Centro universitário UniCeub)

Prof. Francisco De Assis Rocha Neves

(Universidade de Brasília)

Profa. Maria de Fátima Borin

(Universidade de Brasília)

Profa. Carine Royer

(Universidade de Brasília) 
Trabalho desenvolvido no Laboratório de Farmacologia Molecular, Universidade de Brasília, sob a orientação do Prof. Guilherme Martins Santos

Este trabalho teve o apoio financeiro da CAPES e do CNPq. 


\section{AGRADECIMENTOS}

Ao meu orientador, prof. Guilherme Martins Santos, pela oportunidade que ele me deu de trabalhar no seu grupo de pesquisa com um assunto tão emocionante que é a cromatina. Apesar de todas as dificuldades e dos resultados frustrantes que eu tinha no meu caminho, ele sempre foi paciente comigo. Eu agradeço pelas palavras de motivação que ele sempre me dava e pelo espírito de rigor na pesquisa que ele me transmitiu durante esses quatro anos que eu tive privilégio de passar no seu grupo.

Ao prof. Francisco Neves com quem tudo começou, eu agradeço pela oportunidade que ele me deu de sair da minha terra africana para vir fazer pesquisa numa instituição tão valorosa que é a Universidade de Brasília, e mais especialmente o laboratório de farmacologia molecular (FarMol). Ele foi para mim não só um professor mais um grande conselheiro.

À minha colega do grupo, Isabel Torres (Bel) que se tornou uma grande amiga e irmã. Obrigado pelos conhecimentos que você compartilhou comigo e pelas todas as ajudas de diversas formas. Eu desejo para você um bom sucesso no seu caminho na vida de pesquisadora.

Aos outros colegas do grupo, Manuela, Yasmin, Cibele, Vínicius e ao Kaian, com quem sempre compartilhei momentos inesquecíveis.

Às minhas irmãs Pauline, Suzanne (e do seu marido papa Pierre) e Elisabeth que sempre estiveram comigo apesar da distância.

Aos meus colegas do Farmol (Camila, Erica, Jamsom, Sarah, Flora, Alexandre, Pedro, Adria, Carole, Simone, Mariella, Fernanda, Nadyleen, Yasmin, Isadora, Natália, Cynthia, Deelish, Laiza) pelo carinho e por todas as assistências. E também por tornarem o ambiente do Farmol uma casa familiar.

Á Rilva Soares que me ensinou fazer meu primeiro gel de poliacrilamida da minha vida, obrigado por toda sua atenção durante meus primeiros passos na bancada do Farmol.

Á Cristina pela sua colaboração no na secretária do Farmol nos meus primeiros passos áqui

Á Luciano que sempre me dava uma ajuda na secretária do Farmol quando eu precisava 


\section{Á comunidade camaronesa em Brasília pelo seu apoio}

Aos estudantes africanos de Brasília que sempre me apoiaram e me davam a motivação de estudar para ajudar nosso continente.

Á todos os professores do Farmol pelas diversas contribuições. Principalmente a Prof ${ }^{a}$ Angélica Amato que sempre me deu suporte quando eu necessitava.

Ao meu pai por quem tenho um pensamento especial, apesar das todas as dificuldades de saúde que ele passava e da distância, sempre torceu para meu sucesso. Essa tese é dedicada a ele. 


\section{RESUMO}

O DNA em seres eucarióticos é organizado na forma de cromatina, sendo esta a principal responsável pela regulação de diversas atividades vitais para célula, como a transcrição e manutenção do genoma. A cromatina é um complexo formado por unidades repetitivas de nucleossomos e pode se apresentar na forma aberta (10nmpermissiva) ou fechada (30nm- repressiva). Está evidente que a dinâmica de modulação da estrutura da cromatina determina a resposta transcricional e consequentemente o desfecho clínico. Desta forma, com objetivo de se analisar a dinâmica da cromatina, (i) procuramos estabelecer o desenvolvimento de uma metodologia in vitro para o estudo estrutural da cromatina. Em seguida, (ii) objetivamos estudar a ação do etanol, um agente desidratante, sobre a formação do mononucleossomo e de longas fibras de cromatina reconstituídos in vitro e (iii) estabelecer a concentração ideal de colesterol para induzir a formação do cromatossomo, complexo nucleossomo e linker histona (H5). Observamos, por ensaios bioquímicos que o etanol aumenta a estabilidade do mononucleossomo e auxilia a formação de fibras de cromatina de 10nm. Contudo, não observamos nenhum efeito do etanol sobre a formação da fibra de $30 \mathrm{~nm}$ reconstituída in vitro. Além disso, determinamos a concentração mínima e máxima de colesterol capaz de induzir a formação do cromatossomo. Esses resultados sugerem que o etanol e colesterol possam auxiliar os estudos estruturais da cromatina reconstituída in vitro e que a desidratação da cromatina, através destes agentes, possa afetar a dinâmica da cromatina. Ainda desconhecemos os efeitos fisiológicos destes achados, mas nossos resultados apontam para um novo campo de pesquisa ainda inexplorado, onde pequenas moléculas ligantes de nucleosssomo afetam a estrutura da cromatina.

Palavras chaves: Nucleossomo, cromatossoma, etanol, colesterol, estabilidade. 


\begin{abstract}
The DNA in eukaryotic beings is organized in the form of chromatin, which is one of the main molecule responsible for the regulation of vital activities in the cell, such as transcriptional process and genome maintenance. Chromatin is a complex formed by a repetitive units call nucleosomes .It can be present in an open (10nm-permissive) or closed (30nm-repression) structure. It is now evident that the transcriptional response is related to the chromatin structure and dynamic and this determines clinical outcome. In this way, in order to analyse the dynamics of chromatin, we first seek to establish an in vitro methodology for the structural study of chromatin. Therefore, the objectives were to study the action of ethanol, a dehydrating agent, on the formation of mononucleosome and long fibres of chromatin reconstituted in vitro and; II) study the action of cholesterol on the formation of chromatosome, a nucleosome and linker histone (H5) complex. We observe, through biochemical assays that ethanol increases the stability of the mononucleossome and helps in the formation of $10 \mathrm{~nm}$ chromatin fibres. However, we have noticed no effect of ethanol on the formation of the $30 \mathrm{~nm}$ fibre reconstituted in vitro. Moreover, we observe that the cholesterol induces the formation of chromatosome. These results suggest that ethanol and cholesterol may help in the structural studies of chromatin reconstituted in vitro and that dehydration of chromatin, through these agents, can affect his dynamics .We still don't know about the physiological effects of these findings, however, our results pointed out a new research field still unexplored where small molecules are able to bind to mononucleosome and affect the chromatin structure
\end{abstract}

Keywords: Nucleosome, Chromatosome, Ethanol, Cholesterol, stability 


\section{ÍNDICES DE ILUSTRAÇÕES}

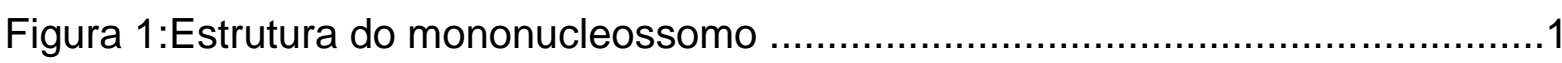

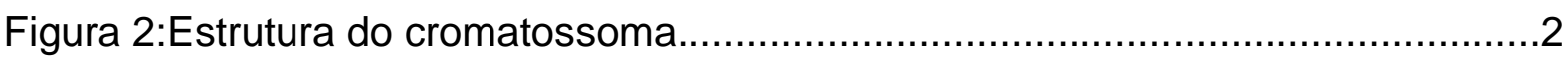

Figura 3:Comparação das estruturas de fibras de $30 \mathrm{~nm}$ com diferentes arranjos......3

Figura 4: Localização assimétrica da Histona $\mathrm{H} 1$ no mononucleossomo.....................3

Figura 5: Níveis de compactação do DNA até o cromossomo....................................

Figura 6: Esquema dos modelos de fibra de 30nm.............................................6

Figura 7:Estrutura atômica do do tetranucleossomo..............................................

Figura 8: Efeito das enzimas HDAC e HAT sobre a estrutura da cromatina..............9

Figura 9: Estrutura química da molécula de etanol...........................................11

Figura 10: .Estrutura química da molecular de colesterol....................................12

Figura 11: Integridade das histonas utilizadas................................................17

Figura 12: Exemplo de plasmídeo pUC18 que possui o arranjo 197.25 flanqueado

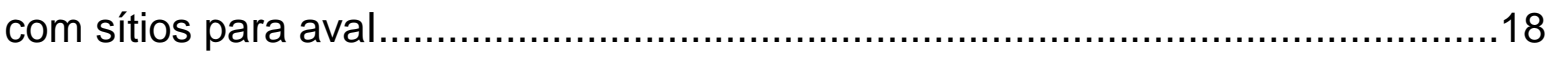

Figura 13: Esquema ilustrativo das etapas realizadas na reconstituição da cromatina

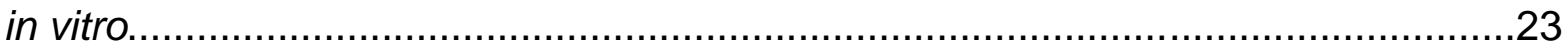

Figura 14: llustração da formação de mononucleossomo.......................................24

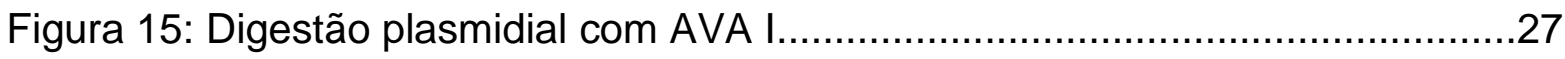

Figura 16: Precipitação de DNA com PEG......................................................27

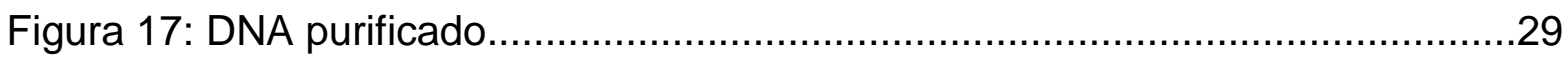

Figura 18: Titulação de octâmero de histonas sobre o fragmento 167.1 ..................30

Figura 19: Incubação do mononucleossomo com etanol..........................................32

Figura 20: Saturação do mononucleossomo com $1 \mathrm{M}$ de etanol..............................33 
Figura 21: Efeito do etanol no DNA livre

Figura 22: Reconstituição da fibra de cromatina de 10nm na presença e na ausência de etanol. .35

Figura 23: . Reconstituição da Fibra de 30nm em presença e ausência de etanol. 36

Figura 24: Reconst. do cromatossomo em ausência e presença de colesterol $10 \mathrm{X}$

Figura 25: Crosslink do Cromatossoma com gluteraldeido 5\% em ausência e presença de colesterol 


\section{ÍNDICES DE TABELAS}

Tabela 1 :Lista dos produtos químicos utilizados

Tabela 2:Ensaio representativo da reação para reconstituição de mononucleossomo 


\section{LISTA DE ABREVIATURAS E SIGLAS}

ATP - Adenosina Trifosfato

crDNA - DNA competidor

EDTA - Ácido Etilenodiamino Tetra-Acético

HAT:Histone acetyl transferaseHDACs - Histonas deAcetil-Transferase

HDL - Lipoproteína de Alta Densidade

HO - Octâmero de Histonas

HUB - Hospital Universitário de Brasília

LB - Luria-Bertani

LDL - Lipoproteínas de Baixa Densidade

MNase - Micrococal Nuclease

MRC - Medical Research Council

NCP - Partícula Central do Nucleossomo (Nucleosome core particle)

NEB - New England Biolab

NRLs - Unidade de Repetição de Nucleossomos (Nucleosome Repeat Length)

P:pelet

PCR - Reação em Cadeia da Polimerase

PEG:Polietilenoglicol

PTMs -Modificações Pós-Traducionais

S:subernagente

SDS-PAGE - Dodecil-Sulfato de Sódio de Poliacrilamida

SMase - Enzima Esfigomielinase

SREBPs - Elemento De Resposta A Esterol (Sterol Regulatory Element-Binding Protein)

TBE - Tris/Borato/EDTA TEA:Trietanolamin 


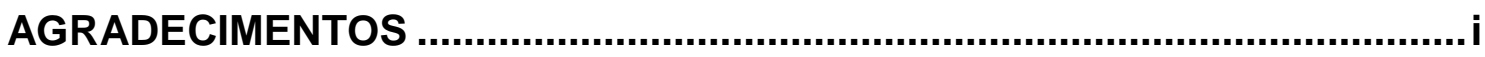

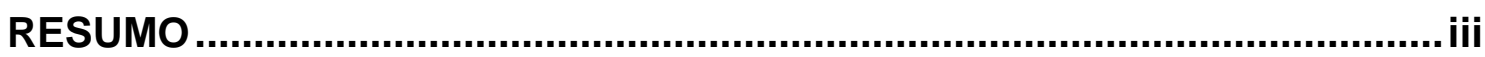

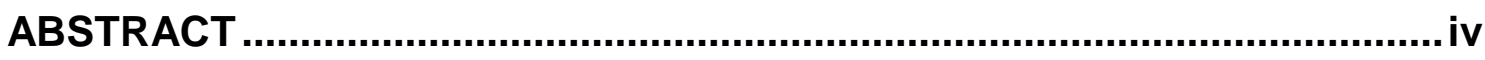

ÍNDICES DE ILUSTRAÇÕES..............................................................

ÍNDICES DE TABELAS .............................................................................. vii

LISTA DE ABREVIATURAS E SIGLAS ................................................... viii

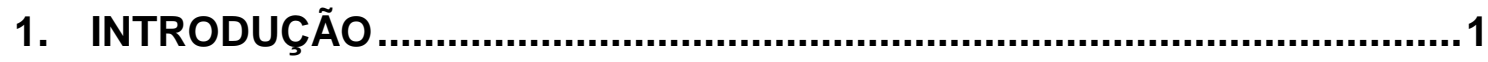

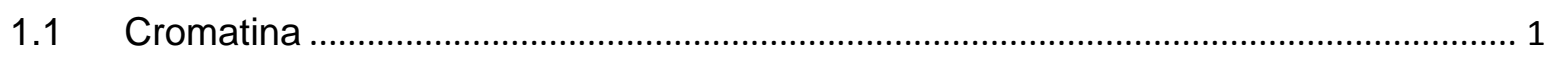

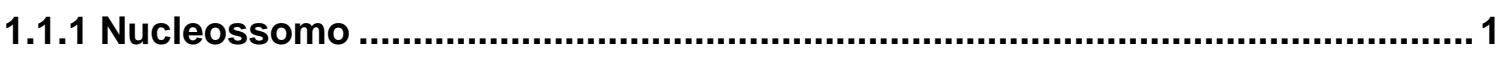

1.1.2 Cromatossomo

1.1.3 Formação da cromatina....................................................................................... 4

1.1.5. Modelos de diferentes topologias da fibra de $30 \mathrm{~nm}$ de cromatina ............................. 5

1.1.5.1 Hélice de um inicio - One start helix................................................................5

1.1.5.1 Hélice de dois inicios - Two start helix.................................................... 6

1.1.2 Regulação da dinâmica da cromatina in vivo ....................................

1.1.3 Modificações pós-traducionais ..........................................................

1.2 Estudo de agentes desidratantes sobre a fibra

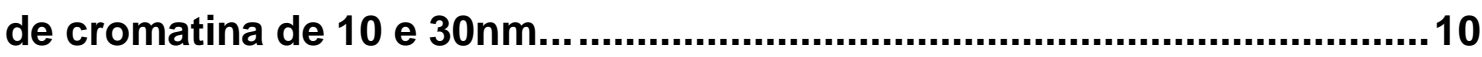

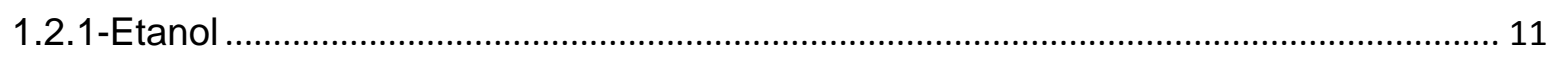

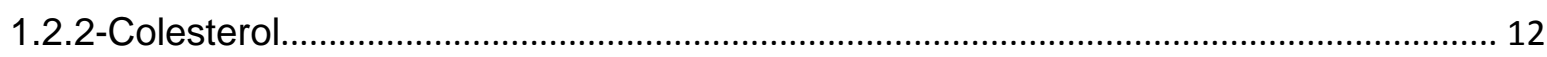

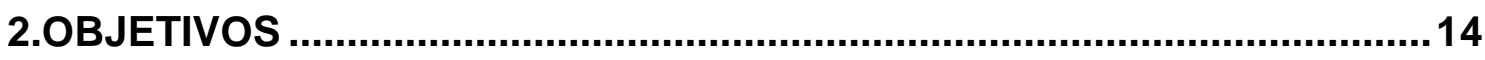

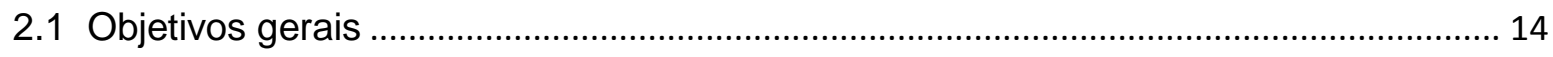

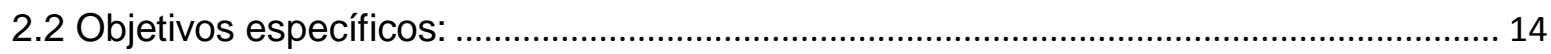

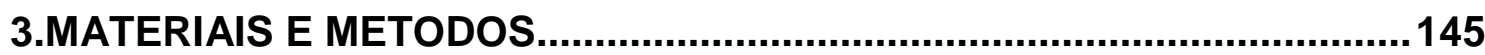

3.1. Produtos químicos e seus fornecedores estão listados na tabela 1 .. 15

3.2. Reconstituição in vitro da cromatina, nucleossomo e cromatossoma16

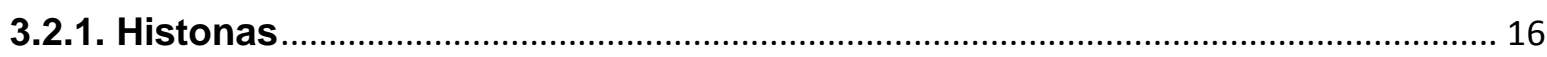

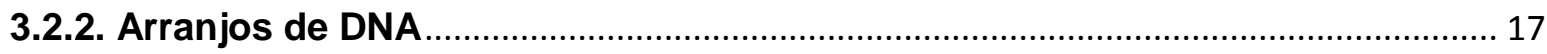

3.2.3 Transformação bacteriana e crescimento para produção de plasmídeos contendo arranjos de DNA 601 ......................................................................... 19

3.2.4 Extração e purificação do DNA …………………………………………………... 19

3.2.4.1 Digestão do DNA plasmidial ........................................................................ 19

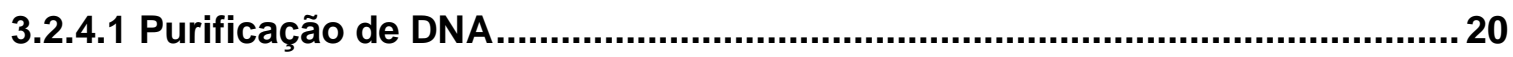




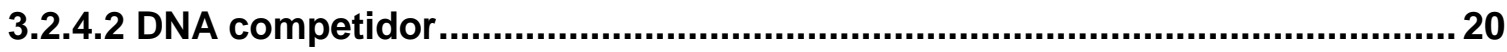

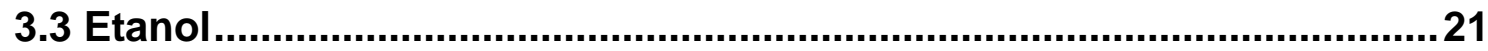

3.4 Colesterol ................................................................................................ 21

3.5. Reconstituição de mononucleossomo e longas fibras de cromatina. 21

3.5.1 - Longas fibras de cromatina ..................................................................................... 21

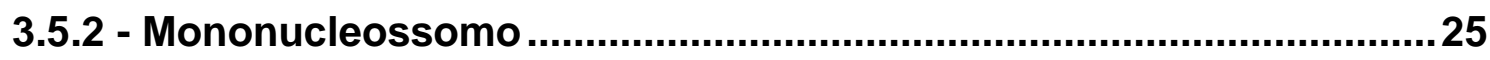

3.5.3 Reconstituição do cromatossomo e tratamento com colesterol ................................... 25

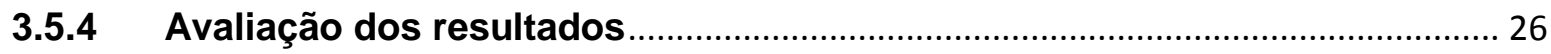

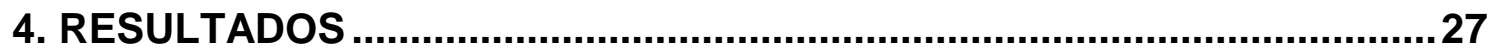

4.1 Digestão e purificação de plasmídeo para obtenção do fragmento DNA 601 -

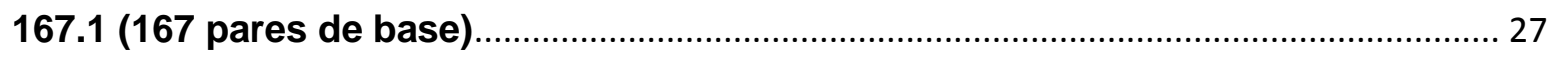

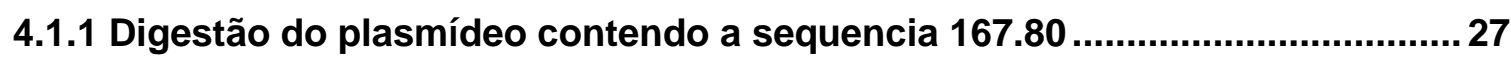

4.1.2 Purificação do fragmento de DNA 601 - 167.1 ........................................ 28

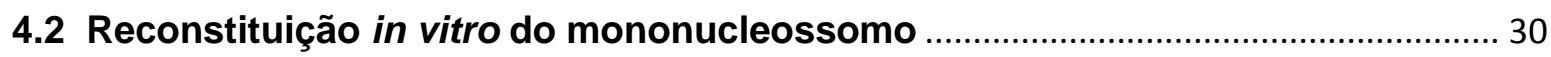

4.3 Etanol aumenta estabilidade do mononucleossomo reconstituído in vitro......... 31

4.4 Efeito do etanol sobre a reconstituição de longas fibras de cromatina in vitro.............. 34

4.4 1. Etanol facilita a reconstituição in vitro de longas fibras de cromatina de

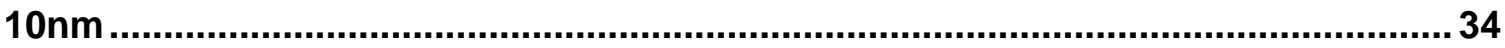

4.4.2 Etanol não apresenta efeito sobre a reconstituição in vitro de fibras de

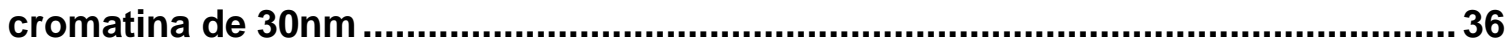

4.4.3 Colesterol estabiliza a formação do cromatossoma in vitro ............................37

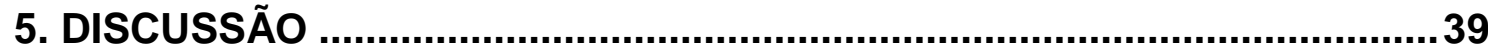

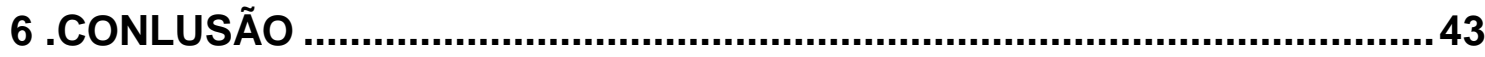

7.PERSPECTIVAS .................................................................................... 44

REFERÊNCIAS ......................................................................................... 45

ANEXO 


\section{INTRODUÇÃO}

\subsection{Cromatina}

\subsubsection{Nucleossomo}

A formação da cromatina é uma estratégia natural usada pelas células eucarióticas para compactar as longas fitas de DNA de aproximadamente 2 metros, dentro do núcleo (1). A cromatina é basicamente constituída de DNA e de proteínas com cargas positivas, chamadas histonas.

O nucleossomo, unidade repetitiva básica da cromatina, é constituído por 145-147 pares de bases de DNA enrolados (1,7 volta) ao octâmero de histonas (2). $\mathrm{O}$ octâmero de histonas é composto por dois dímeros de H2A/H2B e um tetrâmero de $\mathrm{H} 3 / \mathrm{H} 4$ (3) (Figura 1). Este complexo é estabilizado por fortes interações entre o arcabouço de fosfato do DNA e resíduos de arginina e lisinas nas superfícies do domínio globular das histonas do octâmero. A porção N-terminal das histonas, conhecidas como caudas, encontram-se no lado externo do nucleossomo (2). $\mathrm{Na}$ partícula central do nucleossomo (NCP) a ligação entre o DNA e o octâmero de histonas se faz pelas pontes fosfato. Essas ligações são predominantemente não específicas e pode incluir também pontes salinas (4).
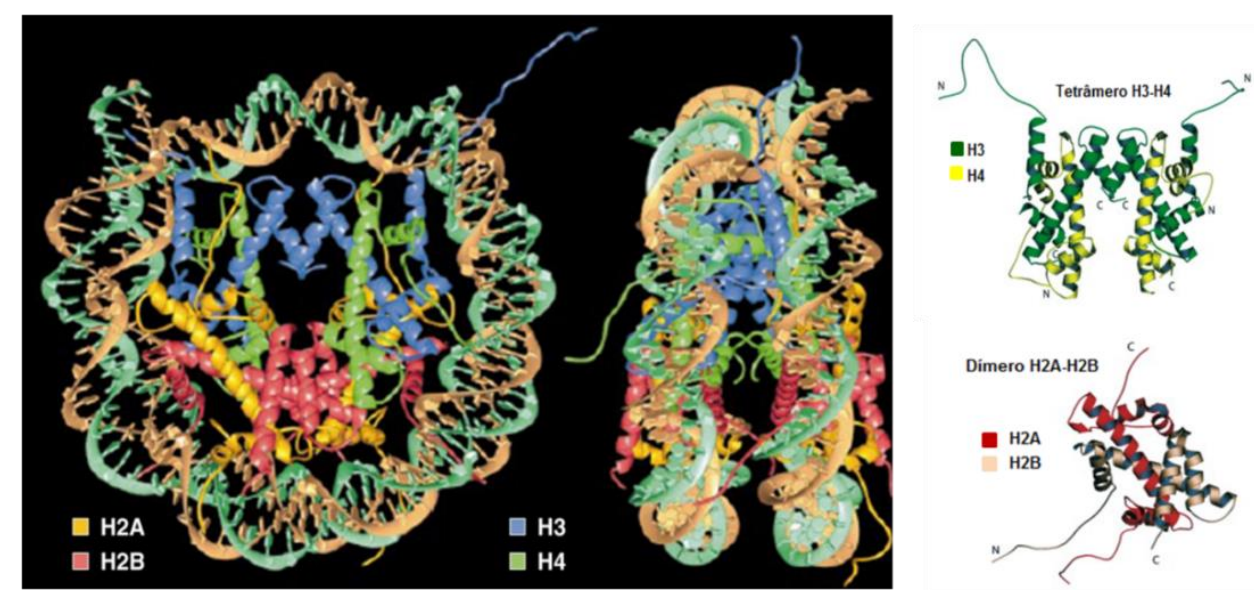

Figura 1. Estrutura do nucleossomo.

a)Visão frontal e lateral da estrutura cristalográfica do nucleossomo de $2.8 \AA$ (PDB 1AOI). (adaptado de (3)) b) Estrutura das histonas que compõe o nucleossomo (adaptado de(5)) 


\subsubsection{Cromatossomo}

Além das histonas que compõem a NCP, existe ainda uma quinta histona, conhecida como linker histona $(\mathrm{H} 1$ ou $\mathrm{H} 5)$. As linker histonas auxiliam na compactação da cromatina, sendo um importante fator para a condensação da cromatina e repressão gênica (6).

O cromatossomo é o nome dado ao complexo formado pelo nucleossomo ligado à linker histona. Existem solidas evidências sugerindo que a linker histona se ligue na dyad do nucleossomo (figura 2) ou seja, no ponto de entrada e saída do DNA sobre o $\mathrm{OH}(7)$.

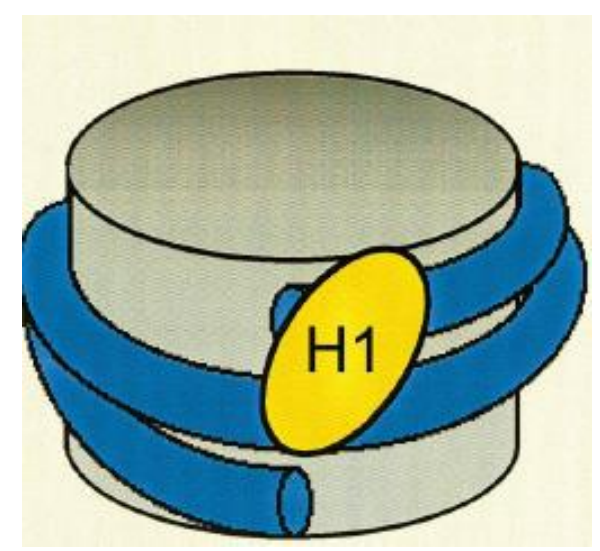

Figura 2. Estrutura do cromatossomo (adaptado de (8).)

A ligação da linker histona é extremamente dependente do comprimento do linker DNA, o DNA que liga uma NCP á outra. Possivelmente, o tamanho mínimo do linker DNA necessário para a formação da uma estrutura de cromatina compactada, fibra de $30 \mathrm{~nm}$, sao 10 pares de bases de cada lado do nucleossomo. De forma geral, tamanhos maiores do linker DNA tendem a favorecer a compactação da cromatina (9).

Em 2014, com o objetivo de estudar a estrutura da fibra de cromatina de $30 \mathrm{~nm}$, Song e colaboradores reconstituíram in vitro as fibras de cromatina com os arranjos 187.12 (187 pares de base repetidas 12 vezes;) e 177.12 (177×12) em presença da linker histona $\mathrm{H} 1$. Os autores observaram, por criomicroscopia 
eletrônica (Cryo-EM), numa resolução de 11 angstrons, que as fibras apresentavam o mesmo padrão (figura 3) da estrutura cristalográfica do tetranucleossomo revelado anteriormente com os linker DNAs retos. As imagens mostraram que existe uma estequiometria de 1 nucleossomo para 1 linker histona (1:1). Em cada um dos 12 nucleossomos constituindo as fibras, as imagens mostraram que a linker histona interage de maneira assimétrica com o nucleossomo;(figura 4); uma grande parte da $\mathrm{H} 1$ se liga a um lado do mononucleossomo e outra a parte menor se liga a outro lado do mononucleossomo (10). A estrutura global destas fibras são compatíveis com o modelo, discutido abaixo, de dupla hélice (zigzag) (figura 4).

$12 \times 187$ bp chromatin

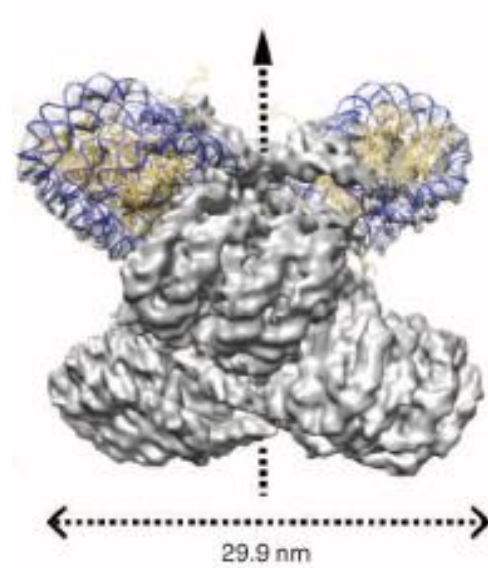

$12 \times 177$ bp chromatin

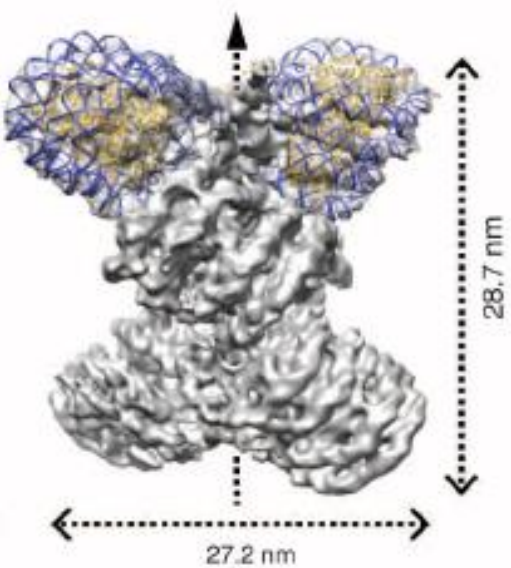

Figura 3 Comparação das estruturas globais de duas fibras de $30 \mathrm{~nm}$ reconstituídas com os arranjos $187.12 \mathrm{pb}$ e $177.12 \mathrm{pb}(10)$

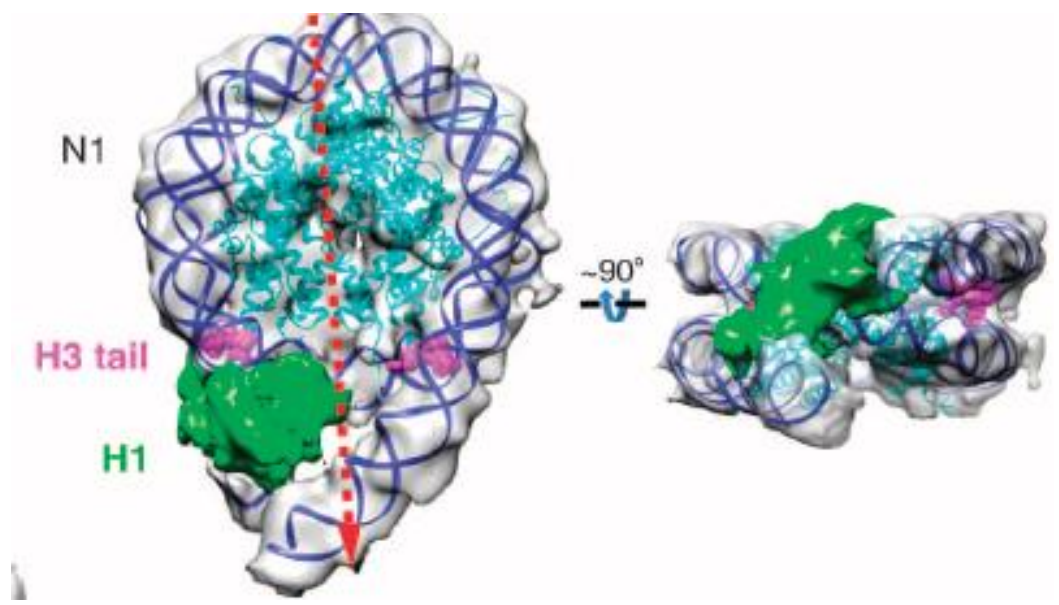

Figura 4: : Localização assimétrica da Histona $\mathrm{H} 1$ no mononucleossomo, vista de 02 ângulos diferentes (10). 


\subsubsection{Formação da cromatina}

Está claro que a estrutura da cromatina é dinâmica e possui um papel muito importante sobre a regulação gênica e manutenção do DNA, consequentemente, sobre a fisiologia celular (11). Desse modo, a compreensão dos processos que determinam a dinâmica da cromatina pode ajudar a desvendar os mecanismos de diversas doenças associadas a transcrição gênica e reparo de DNA.

A formação da cromatina tem como papel fundamental compactar a longa fita de DNA para que ela caiba dentro do núcleo da célula. Na Figura 5 podemos observar os diferentes níveis hierárquicos para a compactação do DNA, onde inicialmente observamos o DNA livre (dupla hélice), seguida pela formação da fibra de $10 \mathrm{~nm}$ e $30 \mathrm{~nm}$, grandes loops de fibras de cromatina e, finalmente, cromossomos.

A cromatina pode se apresentar na forma relaxada (beads on a string ou fibra de $10 \mathrm{~nm}$ ) ou compactada (fibra de $30 \mathrm{~nm}$ ). Em condições fisiológicas, diversos fatores influenciam a formação da fibra de $30 \mathrm{~nm}$, como a presença da linker histona e proteínas que se ligam ao nucleossomo. Além destes, a cauda da histona H4 mostrou-se crucial para a compactação da cromatina. A ligação da cauda da histona $\mathrm{H} 4$ a uma região acídica, formada pelo dímero de $\mathrm{H} 2 \mathrm{~A} / \mathrm{H} 2 \mathrm{~B}$, do nucleossomo adjacente causa aproximação destes (12), fazendo com que a estrutura relaxada se condense. In vitro, a presença de cátions mono ou divalentes que se ligam ao DNA reduzindo sua carga residual, também mostrou-se importante na indução da compactação de longas fibras de cromatina (13). Embora esses fatores tenham sido caracterizados como de grande importância para o mecanismo de compactação, a conformação da estrutura de $30 \mathrm{~nm}$ da cromatina ainda é muito controversa, e sua existência in vivo ainda é discutível $(14,15)$. 


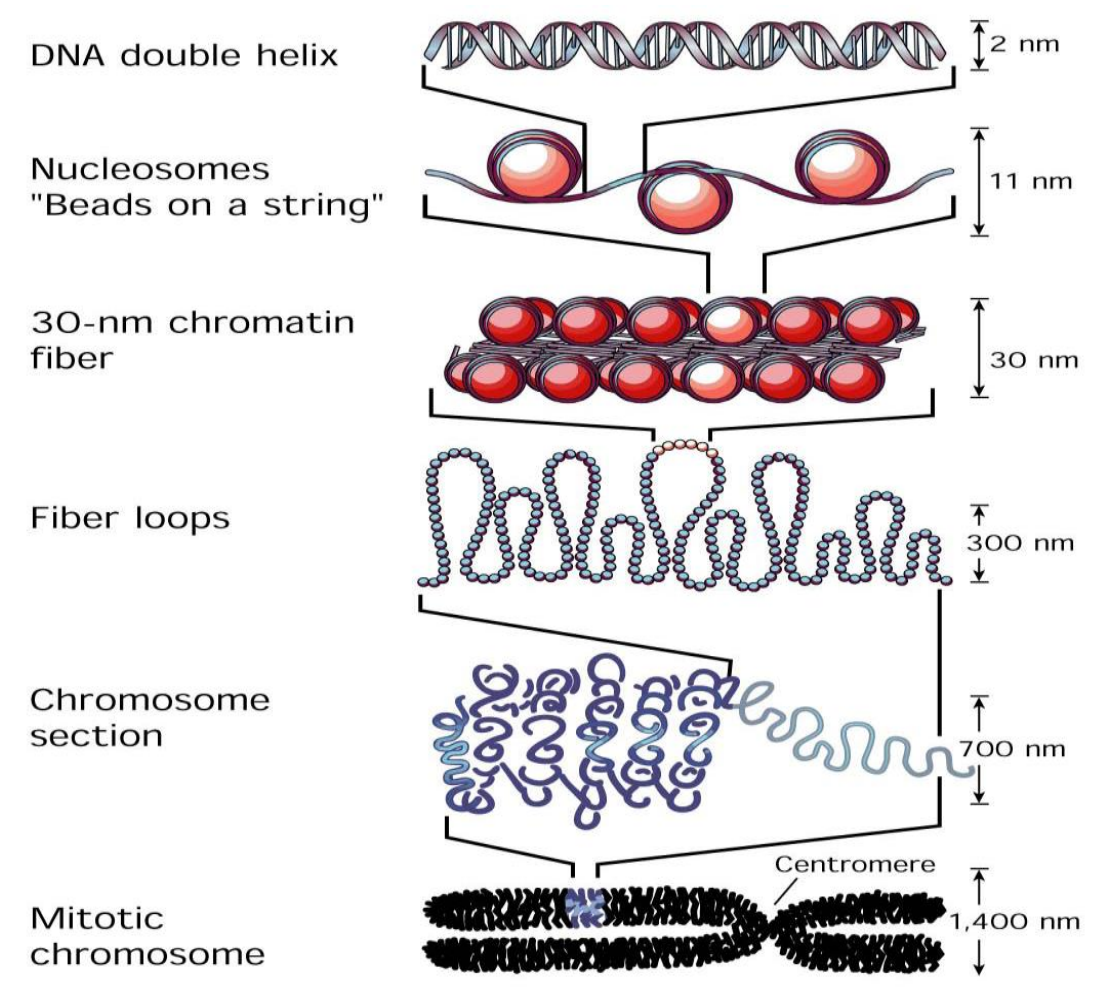

Figura 5: Níveis de compactação do DNA(16)

\subsubsection{Modelos de diferentes topologias da fibra de $30 \mathrm{~nm}$ de cromatina}

Apesar da estrutura cristalográfica do nucleossomo ter sido determinada em 1997, ainda existe muita discussão em relação a estrutura da fibra de cromatina de $30 \mathrm{~nm}$. A utilização de um arsenal de técnicas bioquímicas e biofísicas, como ultracentrifugação analítica, dicroísmo circular, espectroscopia e microscopia eletrônica, permitiram estabelecer dois modelos teóricos para essa estrutura:

\subsubsection{Hélice de um inicio - One start helix}

A hipótese clássica deste modelo é a estrutura solenoide que foi proposta por Finch e Klug em 1976 (17). O modelo solenoide possui uma hélice de início simples em que os nucleossomos adjacentes do filamento (aproximadamente seis nucleossomos por volta) são conectados pelo linker DNA que se dobra para o interior da fibra, caracterizando interações entre os nucleossomos consecutivos (Figura 6a). 


\subsubsection{Hélice de dois inicios - Two start helix}

Este modelo, também conhecido como o modelo zig-zag, é composto por uma ligação reta dos nucleossomos adjacentes, o que implica em interações de nucleossomos alternados (N1 com N3 e N2 com N4) (Figura 6b).

Algumas diferenças significantes para este modelo valem ser ressaltadas, como o tamanho do linker DNA que é diferente entre esses dois modelos. No modelo solenoide são os contatos entre os nucleossomos que definem a dimensão da fibra e o tamanho do linker DNA nao apresenta grande importância. Ao contrário do modelo solenoide, o modelo Zig-zag ressalta o papel do tamanho do linker DNA na dimensão da fibra.

Outro fator fundamental na compactação da fibra é a concentração do sal $(\mathrm{NaCl})$. Em alta concentração de sal $(0,9 \mathrm{M})$, a fibra de $30 \mathrm{~nm}$ poderia aumentar seu dobramento pelas aproximações dos nucleossomos vizinhos. Assim, a formação da estrutura solenoide seria favorecida (17) em relação a zig-zag. Esta ultima, tende-se a formar em meio isotônico, deixando o linker DNA mais livre (relaxado) (18).
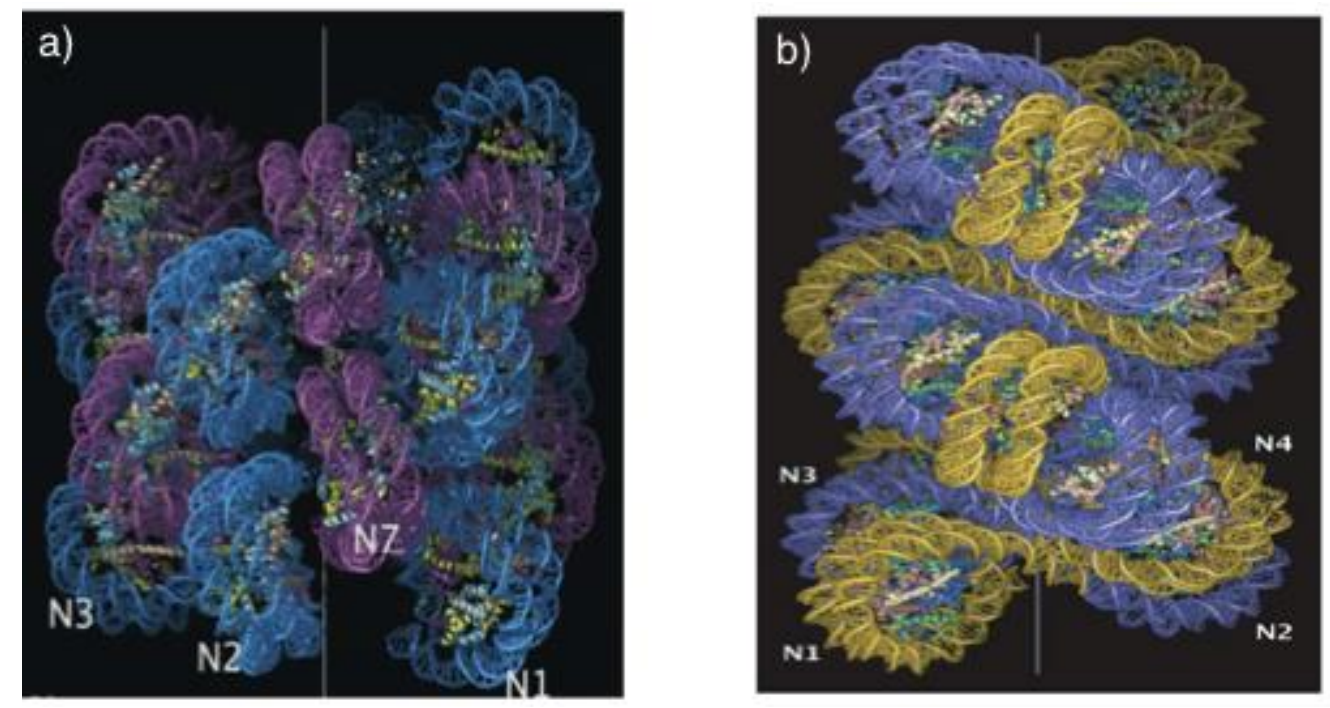

Figura 6:. Esquema dos modelos de fibra de 30nm adaptado de (19). a) Modelo solenoide: interações entre os nucleossomos N1-N2-N3 consecutivos. b) Modelo zig-zag,: interações alternadas.N1-N3,N2-N4,N5-N7.

A hipótese do modelo do zig-zag foi reforçada por Richmond e colaboradores, que em 2005 publicaram a estrutura cristalográfica do tetranuclessomo (PDB,1ZBB)(15). Eles propuseram o modelo baseado numa estrutura em baixa resolução (9 angstrons) e ausência de linker histona. (figura 7) 


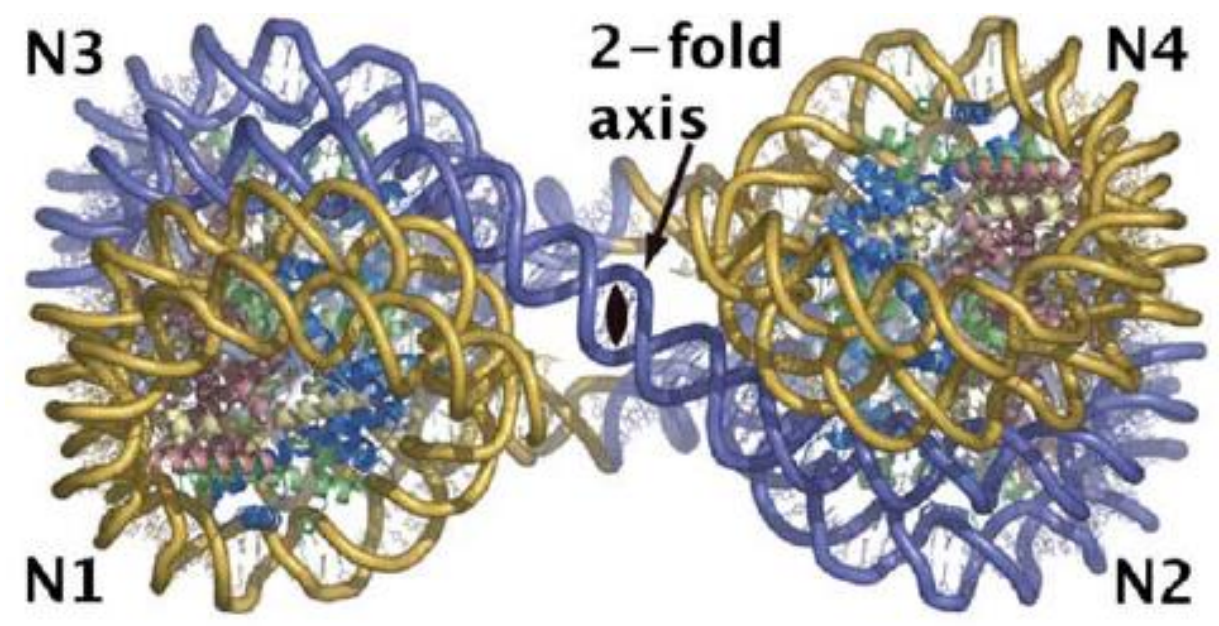

Figura 7. Estrutura atômica do tetranucleossomo mostrando o cruzamento do linker DNA (15).

Como previamente discutido, a recém publicada estrutura da fibra de $30 \mathrm{~nm}$ na presença de linker histona, elucidada por microscopia eletrônica (10) é condizente com a estrutura em zig-zag.

Apesar de todos esses achados, ainda existem dúvidas quanto a prevalência in vivo destes dois modelos.

\subsubsection{Regulação da dinâmica da cromatina in vivo}

No interior da célula, a cromatina apresenta-se predominantemente compactada, gerando uma barreira aos mecanismos de transcrição (20). Para modular o acesso de proteínas ao DNA é necessária uma sofisticada regulação dos níveis de empacotamento da fibra de cromatina, estas são mediadas por três mecanismos: (a) modificações pós-traducionais nas caudas das histonas (21), (b) incorporação de variantes das histonas (22) e (c) remodeladores de cromatina dependentes de ATP(23)

Abaixo, apresento um breve resumo da ação das modificações postraducionais das caudas das histonas sobre a arquitetura da cromatina. 


\subsubsection{Modificações pós-traducionais}

Mudanças pós-traducionais das porções $\mathrm{N}$-terminais das caudas das histonas são determinantes para a regulação transcricional (24). As mudanças de carga das caudas das histonas podem afetar significantemente a arquitetura da cromatina, através da própria ligação da cauda de histonas aos nucleossomos adjacentes, ou ainda pela ligação de proteínas que remodelam a cromatina e/ou interferem com o contato entre DNA - HO (25).

Os fatores de transcrição são responsáveis por recrutar complexos enzimáticos ao DNA alvo, fazendo com que ocorra a deposição ou remoção de grupamentos químicos, ou seja, as moficacões pós-traducionais, que por sua vez atuarão na remodelagem da cromatina ativando ou reprimindo a expressão gênica (26).

As modificações pós-traducionais de histonas mais estudadas são acetilação, metilação, fosforilação e ubiquinação. A acetilação se destaca clinicamente por ser alvo de drogas para tratar muitas doenças, como por exemplo o câncer (27). As marcas da acetilação são realizadas pela enzima acetil transferase de histonas (HAT), que depositam o grupamento acetil em caudas de histonas, alterando como estas irão interagir com nucleossomos adjacentes para modular a cromatina. A enzima desacetilase de histonas, por outro lado, são responsáveis por remover os grupamentos acetil das caudas de histonas, conferindo uma carga positiva as caudas de histonas para que esta se ligue a uma região acida no nucleossomo adjacente (28). Vale ressaltar que estas enzimas atuam também em proteínas que não sejam histonas, podendo afetar a sinalização celular (29). Quando existe um desequilíbrio de expressão destas enzimas, HAT e HDAC, e consequente nível de acetilação, é observado um forte impacto expressão genica global, mas em particular genes envolvidos na proliferação celular, apoptose, e via imune (30).

A figura 8 mostra a acetilação e desacetilação das caudas das histonas e seu impacto na estrutura da fibra de cromatina, conduzindo ao relaxamento ou condensação (31). 
A compreensão do mecanismo de drogas que modulam proteínas envolvidas nas modificações pós-traducionais, tais como HDACs, provou ser uma estratégia importante para melhorar ou curar uma variedade de doenças $(32,33)$. Muitos destes compostos, conhecidos como epidrugs, emergem como uma classe importante de drogas em oncologia (34)
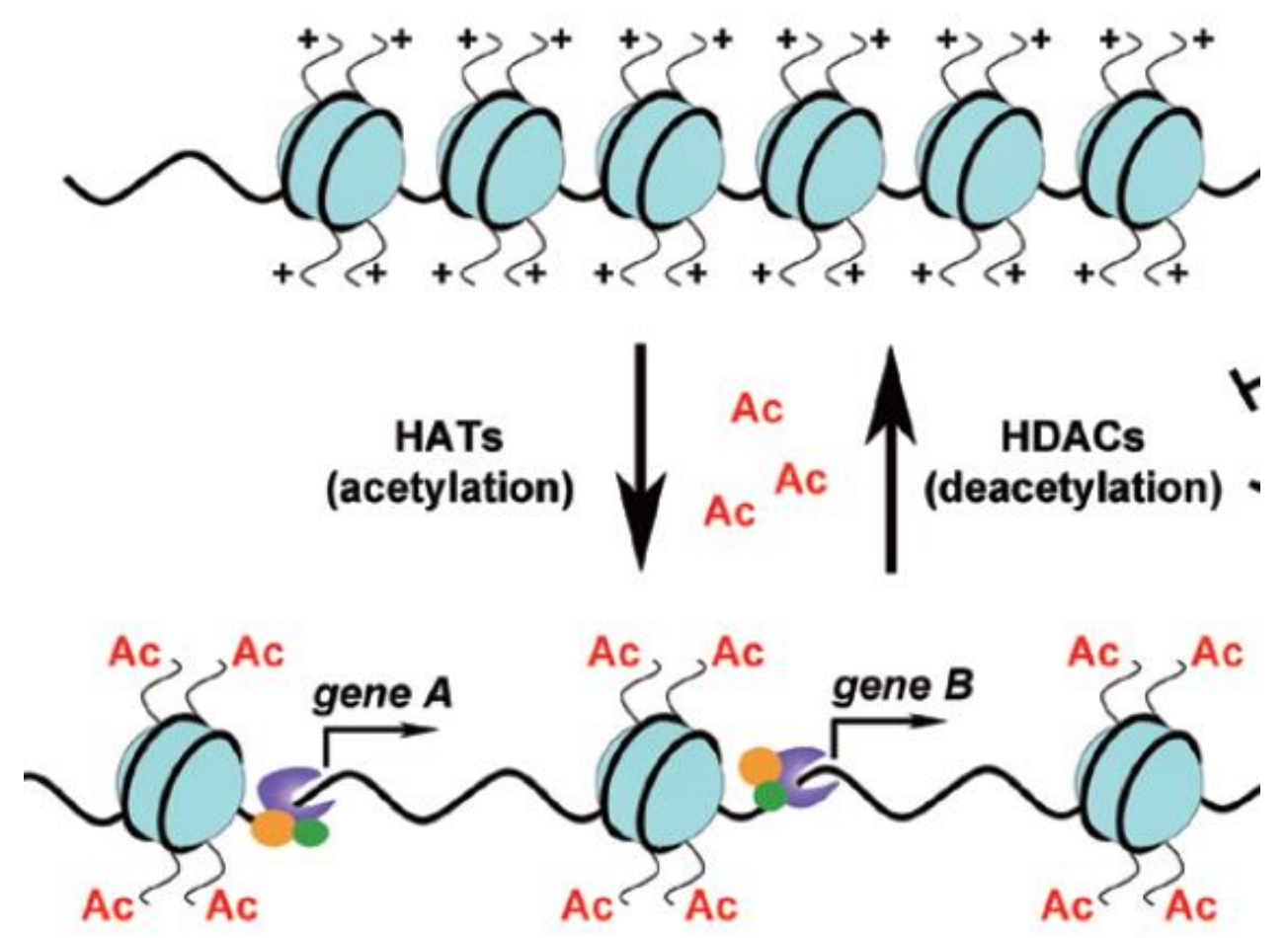

Figura 8: Efeito das enzimas HDAC e HAT sobre a estrutura da cromatina. A abertura da cromatina permite a ligação dos fatores de transcrição que atuarão sobre os genes $A$ e gene $B$ adaptado de (35). 


\subsection{Estudo de agentes desidratantes sobre a fibra de cromatina de 10 e $30 \mathrm{~nm}$.}

O desafio de se obter uma estrutura atômica de cromatina em alta resolução ainda é um dos maiores desejos de diversos biólogos estruturais (36) Desta forma, o estudo de compostos que possam auxiliar na estabilização das fibras de cromatina é de grande importância para guiar os estudos estruturais do nucleossomo e fibras de cromatina. Além disto, a compreensão da ação de fatores que induzem a retirada de água, os agentes desidratantes, sobre a fibra de cromatina pode ter um grande impacto fisiológico ainda inexplorado.

No Laboratório de Farmacologia Molecular da Universidade de Brasília, o grupo do professor Guilherme Martins Santos tem como foco o estudo estrutural da cromatina. O grupo busca as condições ideais de estabilidade das fibras de cromatina capazes de ajudar nos ensaios biofísicos e bioquímicos. Nesse sentido, vários compostos são testados na fase de reconstituição in vitro das fibras. Esse trabalho foca sobre a importância das moléculas de água na organização dos nucleossomos através da utilização de duas moléculas de grande relevância fisiológica, um álcool ;o etanol e um lipídeo ; o colesterol que são capazes de deslocar moléculas de água.

Estudos cristalográficos feitos por Davey e colaboradores (2002) mostraram que o nucleossomo contém aproximadamente 3000 moléculas de água. Uma parte dessas moléculas de água, chamada de água estrutural, participem na formação das ligações hidrogênio entre o DNA e as proteínas (Histonas) (37). A partir deste trabalho, a melhor compreensão do papel das moléculas de água no nucleossomo se tornou crucial para aspectos fundamentais da biologia. Por exemplo, se estas ligações com moléculas de água são potencialmente dinâmicas, então como ficaria o nucleossomo, e cromatina, se este equilíbrio fosse rompido, ou seja, o nucleossomo ficasse "desidratado"? O deslocamento de moléculas de água poderia induzir a formação de uma cromatina condensada? Ainda, com foco em estudos estruturais, desidratar a fibra aumentaria sua estabilidade para realização de trabalhos cristalográficos? 


\subsection{1-Etanol}

$\mathrm{O}$ etanol, de fórmula química $\mathrm{CH}_{3} \mathrm{CH}_{2} \mathrm{OH}$ (Figura 9), também chamado álcool etílico, é um composto orgânico obtido a partir da fermentação de açúcares. As propriedades físicas do etanol vem primariamente da presença de seu grupamento hidroxila e cadeia curta de carbonos. O grupamento hidroxila é capaz de participar de ligações de hidrogênio, fazendo com que este se torne mais viscoso e menos volátil que os compostos orgânicos de peso molecular similares, como o propano.

O etanol é encontrado em bebidas como cerveja, vinho e aguardente, bem como na indústria de perfumaria. Ele também possui grande relevância médica devido a sua utilização em diversos produtos microbiocidas. Ele é especificamente eficaz contra a maioria das bactérias, fungos e vários tipos de vírus, mas se demonstrou ineficaz contra os esporos bacterianos (38).

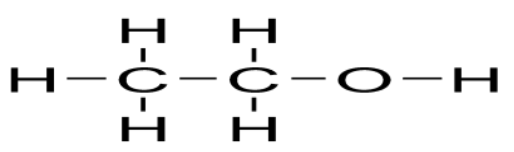

Figura 9. Estrutura química da molécula de etanol.

Os poucos estudos realizados com etanol sobre a cromatina in vivo focaram em análises das mudanças epigenéticas.

Em 1998, Mahadev e Vemuri monitoraram, por dicroísmo circular, as mudanças na cromatina extraídas do núcleo de células hepáticas de ratos submetidos á tratamento crônico de etanol (como bebida). Os resultados mostraram uma significante alteração no padrão de dicroísmo circular da cromatina dos animais tratados. Essa mudança estrutural é uma indicação de que a cromatina pode estar mais condensada (39). Os autores concluem que essas mudanças na cromatina dos ratos tratados com etanol influenciam a regulação da replicação e da transcrição. Potencialmente, essas mudanças observadas sobre a cromatina do fígado podem ser críticas para o mecanismo fisiopatológico da cirrose alcoólica.

Em outro trabalho, Kirpich e colaboradores (2014) demonstraram em hepatócitos de rato que altas doses de etanol aumentam a atividade da histona 
deacetilase HDAC3. Neste estudo, os autores induziram esteatose hepática em ratos através da administração de etanol por gavagem na dose de 4,5g de etanol por $1 \mathrm{~kg}$ de peso. Em comparação com os grupos de controle, as análises bioquímicas, histopatológicas e genéticas dos ratos mostraram um aumento da atividade da HDAC3 no fígado Os autores sugerem que a desregulação da atividade da HDAC e de outros mecanismos epigenéticos causada por doses agudas de etanol podem influenciar o processo da esteatose hepática(40).

\subsection{2-Colesterol}

$\mathrm{O}$ colesterol, $\mathrm{C}_{27} \mathrm{H}_{45} \mathrm{OH}$ é formado por 4 anéis aromáticos, uma cadeia alifática e uma hidroxila $(\mathrm{OH})$ (Figura 10). Esse último fornece à molécula um caráter polar, mas não o suficiente para permitir a dissolução do colesterol em água devido à sua grande porção apolar. O colesterol é considerado como um composto anfipático, ou seja, molécula com uma região polar (solúvel em água) e uma região apolar (não solúvel em água).

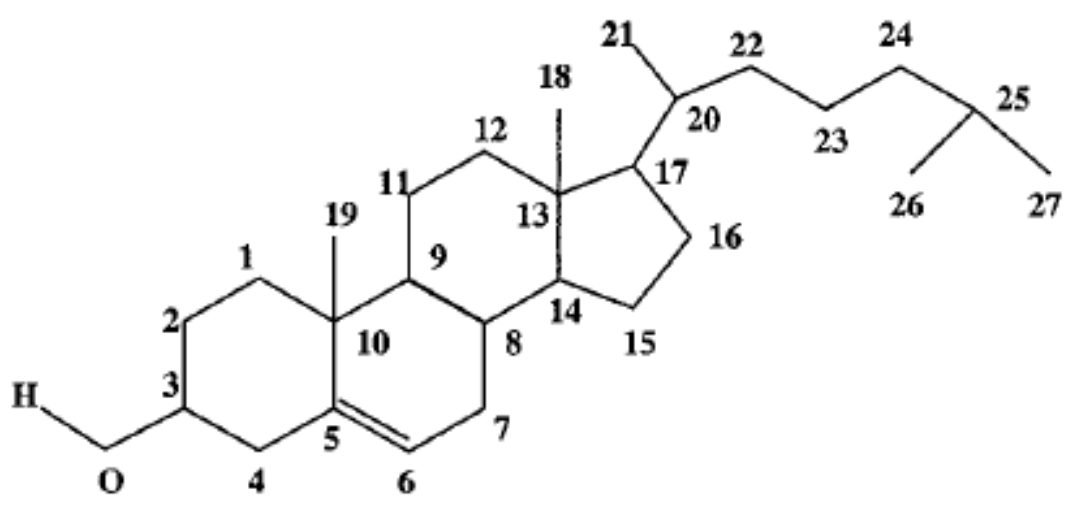

Figura 10.Estrutura química do colesterol (41).

O colesterol é uma molécula crucial para manutenção da integridade da membrana plasmática e na síntese dos hormônios esteroidais, dos quais ele é o principal precursor (42). Por sua característica apolar, o colesterol é transportado no sangue sob a forma de lipoproteínas. As lipoproteínas resultam das associações entre colesterol e duas formas de apo-proteínas (Apo A e Apo B). A apo-proteina-A se liga ao colesterol de alta densidade (HDL) enquanto a apo-B se liga ao colesterol de baixa densidade (LDL). O primeiro (LDL) transporta o colesterol do fígado para 
outros tecidos, enquanto o segundo (HDL) transporta o colesterol dos tecidos para o fígado favorece sua excreção (43).

A síntese do colesterol se faz através de uma enzima chamada HMG-CoA redutase, cuja atividade é regulada pelo nível do colesterol no meio celular. As proteínas de ligação ao elemento de resposta à esterol (SREBP) têm um papel fundamental nesse processo de síntese (44).

O colesterol é encontrado em diversos compartimentos celulares, entretanto as informações sobre a concentração exata do colesterol dentre o meio celular ainda é discutível. Alguns trabalhos mostram que a maior quantidade do colesterol (6590\%) fica na membrana plasmática, representando uma concentração, em média, de $200-300 \mu \mathrm{g} / \mathrm{mg}$ de proteína (45). A quantidade restante encontra-se em outros compartimentos e organelas da célula (46).

O primeiro trabalho a demonstrar a presença do colesterol no núcleo, ao nosso conhecimento, foi correlacionada à interação com a cromatina, sendo observado aproximadamente 10.000 moléculas por núcleo (47). Em 2002, Albi e Magni (2002) isolaram o núcleo das células em regeneração do fígado de camundongos para extração e caracterização da cromatina. Interessantemente, o colesterol estava presente em uma proporção igual a da esfingomielina e representava $9 \%$ do total dos fosfolipídios. Esse trabalho evidenciou, pela primeira vez, o colesterol como um componente da cromatina, e que uma parte desse colesterol fica livre dentro o meio nuclear enquanto outra parte formava um complexo com a esfingomielina e proteínas. Além disso eles conseguiram comprovar que esse colesterol ligado à cromatina tinha uma influência na proliferação celular durante a regeneração das células do fígado (48)

Com base no que foi exposto, observamos que a ação de agentes desidratantes de grande relevância fisiológica, como o etanol e colesterol, podem apresentar um papel importante no controle da arquitetura da cromatina e, consequentemente, na regulação gênica e manutenção do genoma. Desta forma, neste trabalho procuramos dissecar o papel destes agentes sobre a estrutura da cromatina reconstituída in vitro. 


\section{OBJETIVOS}

2.1 Objetivos gerais

O objetivo principal deste estudo é compreender o papel de moléculas desidratantes, etanol e colesterol, sobre a estrutura da cromatina, através do uso de longas fibras de cromatina e cromatossoma reconstituídos in vitro. Desta forma, procuramos compreender como o dinâmico equilíbrio da ligação de moléculas de água aos nucleossomos afetam a estrutura da cromatina.

\subsection{Objetivos específicos:}

- Estabelecer metodologia de reconstituição de mononucleossomo in vitro.

- Purificar o DNA com forte posicionamento de octâmeros de histonas para reconstituir o mononucleossomo.

- Realizar a reconstituição in vitro de mononucleossomo, cromatossomo e longas fibras de cromatina utilizando $\mathrm{HO}$ purificados de eritrócitos de galinha.

- Observar a ação do etanol sobre longas fibras de 10 e $30 \mathrm{~nm}$ de cromatina reconstituídas in vitro.

- Determinar a concentração ideal de colesterol para formação do cromatossomo 


\section{MATERIAIS E METODOS}

\subsection{Produtos químicos e seus fornecedores estão listados na tabela 1}

\begin{tabular}{|c|c|}
\hline Produtos & Fornecedores \\
\hline $\begin{array}{l}\text { Colesterol (cholesterol solution } 500 x, \\
\text { animal componente free) }\end{array}$ & Sigma-Aldrich \\
\hline Etanol (álcool etílico absoluto anidro) & J.T Barker \\
\hline Enzimas & NEB \\
\hline Agarose & Sigma-Aldrich \\
\hline EDTA, & $\begin{array}{l}\text { Dinâmica (Quimica contemporânea } \\
\text { Ltd) }\end{array}$ \\
\hline TRIS & Sigma-Aldrich \\
\hline $\mathrm{NaCl}$ & VETEC \\
\hline TEA & VETEC \\
\hline PEG & Sigma-Aldrich \\
\hline Acidio bórico & PlusOne \\
\hline $\mathrm{HCl}$ & VETEC \\
\hline TEMED & PlusOne \\
\hline Acrilamida & PlusOne \\
\hline ÁGUA & MilliQ \\
\hline Brometo d'etidio & Fisherbiotech \\
\hline Comassi Blue & MERCK \\
\hline
\end{tabular}

Tabela 1:Lista dos produtos químicos utilizados 


\subsection{Reconstituição in vitro da cromatina, nucleossomo e cromatossoma}

Os matérias primas para reconstituição são: o DNA, as histonas e os tampões

\subsubsection{Histonas}

Foram usadas histonas de galinhas extraídas e purificadas pelo prof. Dr. Guilherme Santos, no Laboratório de Biologia Molecular do MRC (Medical Research Council). Brevemente, o protocolo (9) para purificação do HO consistiu em:

1. Filtração e lavagem do sangue de galinha com posterior centrifugação, a fim de decantar os eritrócitos;

2. Lise dos eritrócitos em tampão contendo sais, agente redutor, EDTA e Triton, com a liberação de núcleos intactos, separados por centrifugação e novamente lavados com o mesmo tampão, até que os núcleos estivessem brancos e o sobrenadante incolor;

3. Isolamento de longos fragmentos de cromatina: digestão da cromatina com a enzima Micrococal Nuclease (MNase) a $37^{\circ} \mathrm{C}$, lise do núcleo e separação dos detritos celulares da cromatina por centrifugação. Os longos fragmentos de cromatina foram purificados em coluna de filtração em gel (Sepharose 4B$\mathrm{Cl})$;

4. Purificação do octâmero de histonas: longos fragmentos de cromatina foram concentrados e trazidos à concentração de 3M de $\mathrm{NaCl}$. Nesta concentração, o HO dissocia do DNA, porém, permanece como octâmero. Remoção do DNA usando coluna de hidroxiapatita (liga ao DNA e HO sai no void volume);

5. Para remover qualquer histona que possivelmente tivesse se desvinculado do complexo, foi feita purificação final dos HO por filtração em gel (coluna Superdex 200);

As histonas foram armazenadas a $-20^{\circ} \mathrm{C}$ e estocadas em $50 \%$ de glicerol, agente crioprotetor, e em alta concentração de sal (3M NaCl), para manter a estabilidade das proteínas. A integridade dos estoques foi checada por eletroforese em gel desnaturante de poliacrilamida 14\% (SDS-PAGE) (Figura 11). 


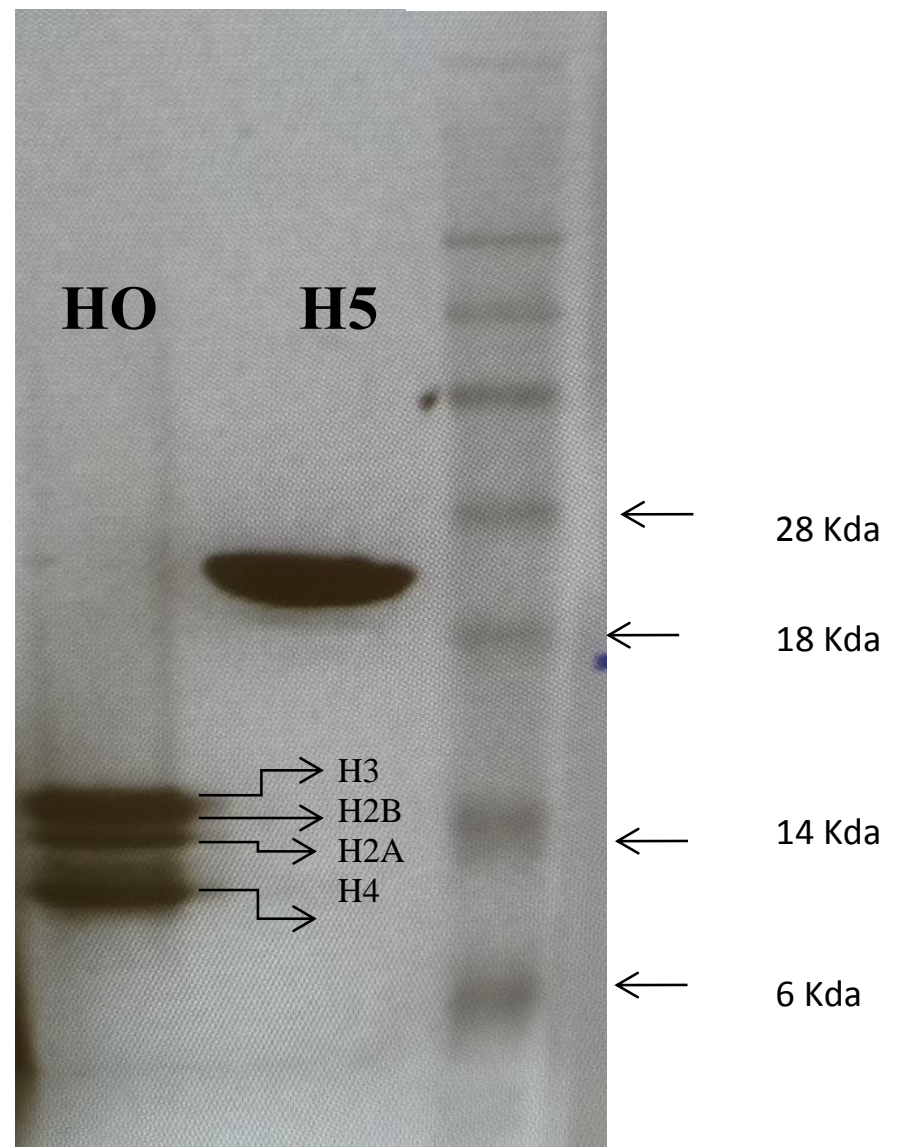

Figura11. Integridade das histonas utilizadas.

Gel de SDS-PAGE 14\% corado com solução de Comassie Blue.

Como pode ser observada, as histonas ( $\mathrm{OH}$, e H5) não sofrem de problema de proteólise e portanto podem ser usadas para reconstituir nossas fibras e nucleossomos.

\subsubsection{Arranjos de DNA}

O DNA utilizado para a reconstituição do mononucleossomo e cromatina é a sequência "601 DNA", que possui 147pb, que pode estar dimerizada formando diferentes arranjos de DNA. Este DNA, isolado em 1998 por Widom e Lowary, foi obtido através de um pool de moléculas sintéticas de DNA aleatórias (49). Desta forma, os autores identificaram a sequência de maior afinidade com o octâmero de histonas. Essa sequência de DNA permite obter uma correta estequiometria de HOs ligadas ao DNA.

Os arranjos são sequências do "DNA 601", repetidas inúmeras vezes com diferentes comprimentos de linker DNA. Nesse trabalho usamos:

- 167.80 (147pb + 20pb linker DNA- repetidos 80 vezes)

- 177.36 (147pb + 30pb linker DNA- repetidos 36 vezes) 
Os plasmídeos contendo diferentes arranjos de DNA foram cedidos pela pesquisadora Dra. Daniela Rhodes, do Laboratório de Biologia Molecular do MRC. Em resumo, o protocolo (14) utilizado para construção dos arranjos foi:

1. A sequência (601 DNA) foi amplificada por reação em cadeia da polimerase (PCR) com a utilização de primers desenhados contendo sítios de restrição para EcoRI, EcoRV, Xbal;

2. O "DNA 601" foi excisado com as enzimas de restrição EcoRI/Xbal e clonado em um vetor (pUC18);

3. Multimerização: os clones foram transformados e crescidos em DH5a e E.coli, e posteriormente purificados e digeridos com a enzima Aval. Os fragmentos de "DNA 601" foram unidos com a enzima T4 DNA ligase;

4. Os produtos foram fracionados por corrida eletroforética em gel nativo de agarose $1,2 \%$ e as bandas do gel de interesse (arranjos desejados) foram extraídas e purificadas;

5. Os arranjos foram então ligados em vetor pUC18 que possui resistência a ampicilina e regiões flanqueadoras com sítios para Aval .A figura 12 mostra um exemplo de plasmídeo pUC18 que possui o arranjo 197.25 flanqueado com sítios para Ava I

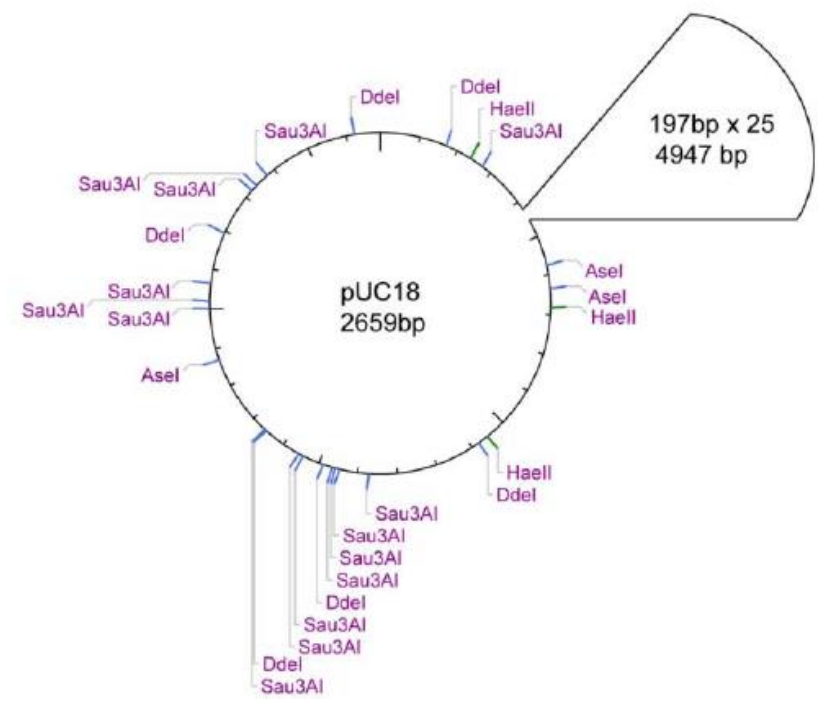

Figura 12:Exemplo de plasmídeo pUC18 que possui o arranjo 197.25 flanqueado com sítios para Aval (50) 


\subsubsection{Transformação bacteriana e crescimento para produção de plasmídeos contendo arranjos de DNA 601}

Células DH5a foram transformadas com os plasmídeos por meio da técnica de choque térmico (Protocolo de Técnicas de Biologia Molecular do Laboratório de Farmacologia Molecular). Após esse procedimento foi feita a adição de $100 \mu \mathrm{L}$ de meio de cultura LB (Luria-Bertani) e incubação a $37^{\circ} \mathrm{C}$ por 30 minutos, sob agitação constante, para replicação das bactérias. A seleção das bactérias transformadas (contém o gene de resistência a ampicilina) foi feita através do plaqueamento de $50 \mu \mathrm{L}$ do tubo da solução anterior em placa contendo meio LB sólido com $0,1 \mathrm{mg} / \mathrm{mL}$ de ampicilina por 12 horas a $37^{\circ} \mathrm{C}$.

As colônias resistentes a ampicilina foram coletadas e crescidas em $5 \mathrm{~mL}$ de meio de cultura LB contendo $60 \mathrm{mg} / \mathrm{mL}$ de ampicilina (incubado a $37^{\circ}$ sob agitação constante). Passadas oito horas de crescimento bacteriano, transferiu-se o conteúdo para erlenmeyer contendo $1 \mathrm{~L}$ de meio LB com ampicilina (mesma concentração usada anteriormente) e incubou-se novamente a $37^{\circ}$ sob agitação constante, por 12 horas.

\subsubsection{Extração e purificação do DNA}

Após o crescimento fizemos a extração e purificação do DNA utilizando Max preparação plasmidial conforme protocolo adaptado pelo Laboratório de Farmacologia Molecular

\subsubsection{Digestão do DNA plasmidial}

Após a obtenção do DNA plasmidial puro, realizamos a digestão dos plasmídeos para o futuro isolamento do fragmento de DNA de interesse.

$\mathrm{O}$ arranjo 167.80 foi digerido em pequenos fragmentos de $167 \mathrm{pb}$ com a enzima de restrição Ava I (New England Biolabs) por $8 \mathrm{~h}$ a $37^{\circ} \mathrm{C}$. Posteriomente, por eletroforese em gel nativo de agarose $1 \%$, observamos a completa digestão do plasmídeo em 2 fragmentos: o inserto de interesse com 167pb, e o esqueleto do plasmídeo com 2659pb. 
Quanto ao 177.36, e o fragmento de DNA desejado foi excisado dos plasmídeos com o uso da enzima de restrição EcoRV (New England Biolabs) por 2h a $37^{\circ} \mathrm{C}$. Posteriormente, o esqueleto do plasmídeo foi digerido com outras enzimas (Dral/Haell/Xbal - New England Biolabs) por mais $2 \mathrm{~h}$ a $37^{\circ} \mathrm{C}$ em fragmentos menores, para facilitar a separação dos longos fragmentos. Por eletroforese em gel nativo de agarose $1 \%$ foi possível visualizar as bandas e confirmar a digestão enzimática.

\subsubsection{Purificação de DNA}

A separação do fragmento desejado foi realizada utilizando $2 \%$ de PEG $6000+1,25 \mathrm{M} \mathrm{NaCl}$, que permite a precipitação apenas de longos fragmentos de DNA. Foi feita incubação por 10 minutos no gelo após a adição do PEG 6000 + $1,25 \mathrm{M} \mathrm{NaCl}$ e posterior precipitação por centrifugação a $4^{\circ} \mathrm{C}$ por 20 minutos com velocidade de $4748 \mathrm{~g}$ (13.000 rpm). O sobrenadante foi aspirado para outro tubo de centrífuga e o pellet ressuspendido em $100 \mu \mathrm{L}$ de água. O pellet e o sobrenadante foram avaliados em gel de agarose $1 \%$ contendo brometo de etídeo. Após a primeira precipitação (2\% de PEG) acrescentou-se $0,2 \%$ de PEG ao sobrenadante e repetiuse o protocolo até atingir a concentração de PEG ideal para precipitar o fragmento indesejável (em torno de 7\% PEG). O sobrenadante contendo o fragmento desejado foi então purificado com fenol/clorofórmio, precipitado com etanol e o DNA foi ressuspendido em TE (Tris 10mM; EDTA 1mM)

Quanto ao arranjo 177.36 acrescentou-se $0,5 \%$ de PEG ao sobrenadante e repetiu-se o protocolo até atingir a concentração de PEG ideal para precipitar os longos fragmentos. Após a completa precipitação, juntaram-se todos os pellets, contendo os fragmentos desejados e foi feita purificação com fenol/clorofórmio, precipitação com etanol e a ressuspensão do DNA em TE.

\subsubsection{DNA competidor}

O DNA competidor (crDNA) é uma sequência de 147pb aleatória, que utilizamos na reconstituição de cromatina in vitro, e que se liga com menor afinidade que a sequência 601. Assim, na reconstituição da cromatina, o crDNA previne a supersaturação das fibras de cromatina reconstituídas com arranjos de DNA 601, 
"sequestrando" o excesso de histonas para formar o mononucleossomo. Isso garante que as fibras contenham quantidades estequiométricas de arranjo de DNA $601, \mathrm{HO}$ e linker histona.

Essa sequência (147pb) foi amplificada por reação de polimerase em cadeia (PCR), utilizando primers desenhados para se anelar a uma região aleatória contida no vetor (pUC18).

\subsection{Etanol}

Foi utilizado etanol absoluto anidro e soluções foram predeterminadas por reconstituição a partir de uma solução estoque de 17,14M

\subsection{Colesterol}

Foi utilizada uma solução aquosa de colesterol sintético 500X Este colesterol é patenteado pela Sigma, e apesar de nossos diversos pedidos, não nos foi fornecida a concentração exata. Assim, determinou-se a medida da concentração de colesterol total da solução por método colorimétrico (no laboratório de bioquímica do HUB e no Laboratório Sabin) em três concentrações crescentes: 100X, 200X e $300 X$. Os resultados obtidos foram: $45 \mathrm{mg} / \mathrm{dL}, 88 \mathrm{mg} / \mathrm{dL}$ e $143 \mathrm{mg} / \mathrm{dL}$ respectivamente. A solução estoque de $500 \mathrm{X}$ apresenta a concentração estimada de $225 \mathrm{mg} / \mathrm{dL}$. As concentrações utilizadas nesse trabalho variaram de $1 \mathrm{X}$ a 100X.

\subsection{Reconstituição de mononucleossomo e longas fibras de cromatina}

\subsection{1 - Longas fibras de cromatina}

A reconstituição das fibras longas de cromatina in vitro foi realizada conforme protocolo utilizado no laboratório da Dr. Daniela Rhodes (14).

A reconstituição se inicia com o preparo das soluções de reações individuais em tubos de centrífuga siliconados de $(1,5 \mathrm{~mL})$, contendo o octâmero de histonas (HO) e tampão com alta concentração de sal (2M NaCl, 10mM TEA-HCl pH 7.4, $1 \mathrm{mM}$ EDTA) .O volume total de cada reação é $80 \mu \mathrm{L}$ (Tabela 1). 
A quantidade de DNA de cada reação é $1 \mu \mathrm{g}$.Assim o volume de DNA que tem que ser colocado deve ser em função da concentração da solução estoque de DNA obtida após a purificação com fenol e sua re-suspenção com TE.

\begin{tabular}{|c|l|l|l|l|l|l|}
\hline $\begin{array}{c}\text { Arranjo de DNA } \\
(177.36 / 167.1)(\mu \mathrm{L})\end{array}$ & 4 & 4 & 4 & 4 & 4 & 4 \\
\hline Octamero OH $(\mu \mathrm{L})$ & 0 & 8 & 12 & 16 & 20 & 22 \\
\hline $\begin{array}{c}\text { Tampão de } \\
\text { reconstituição }(\mu \mathrm{L})\end{array}$ & 76 & 68 & 64 & 60 & 56 & 54 \\
\hline
\end{tabular}

Tabela 2. Exemplo de mistura de reação para formação de mononucleossomo.

Cada reação foi transferida individualmente para pequenos tubos de vidro siliconados, que foram fechados com membrana de diálise com poros 3-7 kDa (Snake Skin Pleated Dialysis Tubing - Thermo Sientific), para realização de uma diálise lenta.

Todos os pequenos tubos de vidros foram transferidos de cabeça para baixo, de forma que a solução ficasse em contato com a membrana, para um saco de diálise da mesma membrana anterior (cut-off de 3 ou $7 \mathrm{kDa}$ ), contendo $30 \mathrm{~mL}$ de tampão em alta concentração de sal (2M NaCl, 10mM TEA-HCl pH7.4, 1mM EDTA). Este saco com os tubos foi posteriormente transferido para um béquer contendo um grande volume de tampão (4L) na ausência de sal (10mM TEA-HCl pH 7.4, 1mM EDTA) (Figura 13). Deixou-se dialisando sob agitação lenta a $4^{0} \mathrm{C}$ por $12-20 \mathrm{hs}$. Após a diálise os pequenos tubos de vidro foram retirados do saco de diálise e analisados por eletroforese em gel nativo de agarose 0,8\% para as longas fibras de $10 \mathrm{~nm}$ e poliacrilamida $5 \%$ para mononucleossomos.

Para formação da fibra de 30nm, adicionamos a H5 à fibra de 10nm. Assim, após a determinação do ponto ideal para a formação da fibra de $10 \mathrm{~nm}$, faz-se necessário a titulação de $\mathrm{H} 5$, utilizando uma quantidade de $\mathrm{HO}$ fixa para todas as reações individuais.Assim,após a primeira diálise (12-20h) os tubos foram transferidos para um segundo recipiente com $2 \mathrm{~L}$ de tampão contendo $10 \mathrm{mM}$ TEA-HCl pH 7.4 e $1 \mathrm{mM}$ $\mathrm{MgCl}$, promovendo mais uma diálise de 12-20hs, também sob lenta agitação (sem 
o saco de diálise). Esse tampão é necessário, pois além da linker histona é necessários cátions mono ou bivalentes para a formação da fibra compactada.

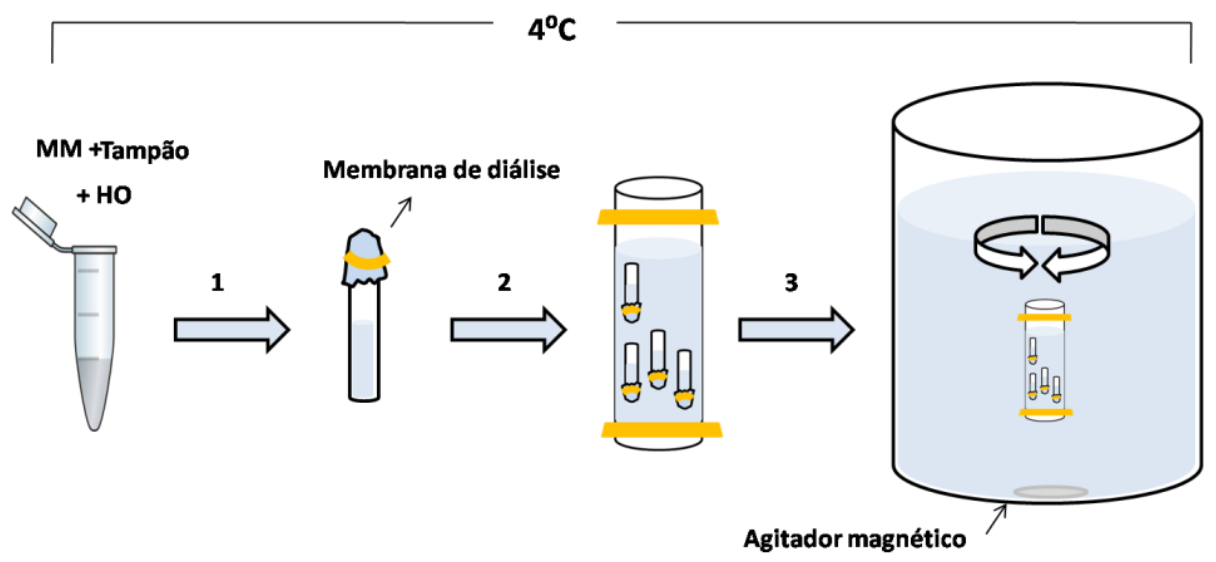

Figura 13. Esquema ilustrativo das etapas realizadas na reconstituição in vitro do mononucleossomo e das fibras de cromatina de $10 \mathrm{~nm}$ e $30 \mathrm{~nm}$.

(Desenho de Isabel Torres e Manuela Leite)

Etapa 1: Adição dos componentes da reações (DNA,tampõ,OH) dentro um tube ependorf e tranferêcia dessa mixtura para pequenos tubos de vidro siliconados fechados com membrana de diálise.

Etapa 2: transferência dos tubos de vidro de cabeça para baixo para um saco de diálise em alta concentração de sal.

Etapa 3: transferência do saco de diálise contendo os tubos de vidro para um béquer com tampão na ausência de sal. Diálise overnight, sob agitação lenta, a $4^{\circ} \mathrm{C}$.

Os tubos de centrífuga e os de vidro, como dito, devem ser todos revestidos internamente com silicone, para evitar a perda de $\mathrm{OH}$, que se adere facilmente a superfícies ásperas.

Os três ambientes de diálise e a agitação moderada são essenciais para que ocorra uma diálise lenta, o que promove a ligação do octâmero de histonas, de forma organizada e preferencial, após a total diálise, o sistema encontra-se em equilíbrio, com todos os ambientes com a mesma concentração de sal (aproximadamente $15 \mathrm{mM}$ de $\mathrm{NaCl}$ ).(Figura14)

Para avaliar o efeito do etanol durante a formação dessas fibras (10 e 30nm) este foi incluído no tampão de reconstituição. Já para avaliar o efeito sobre o mononucleossomo o etanol foi incubado com o complexo formado por $2 \mathrm{~h}$ em temperatura ambiente. 


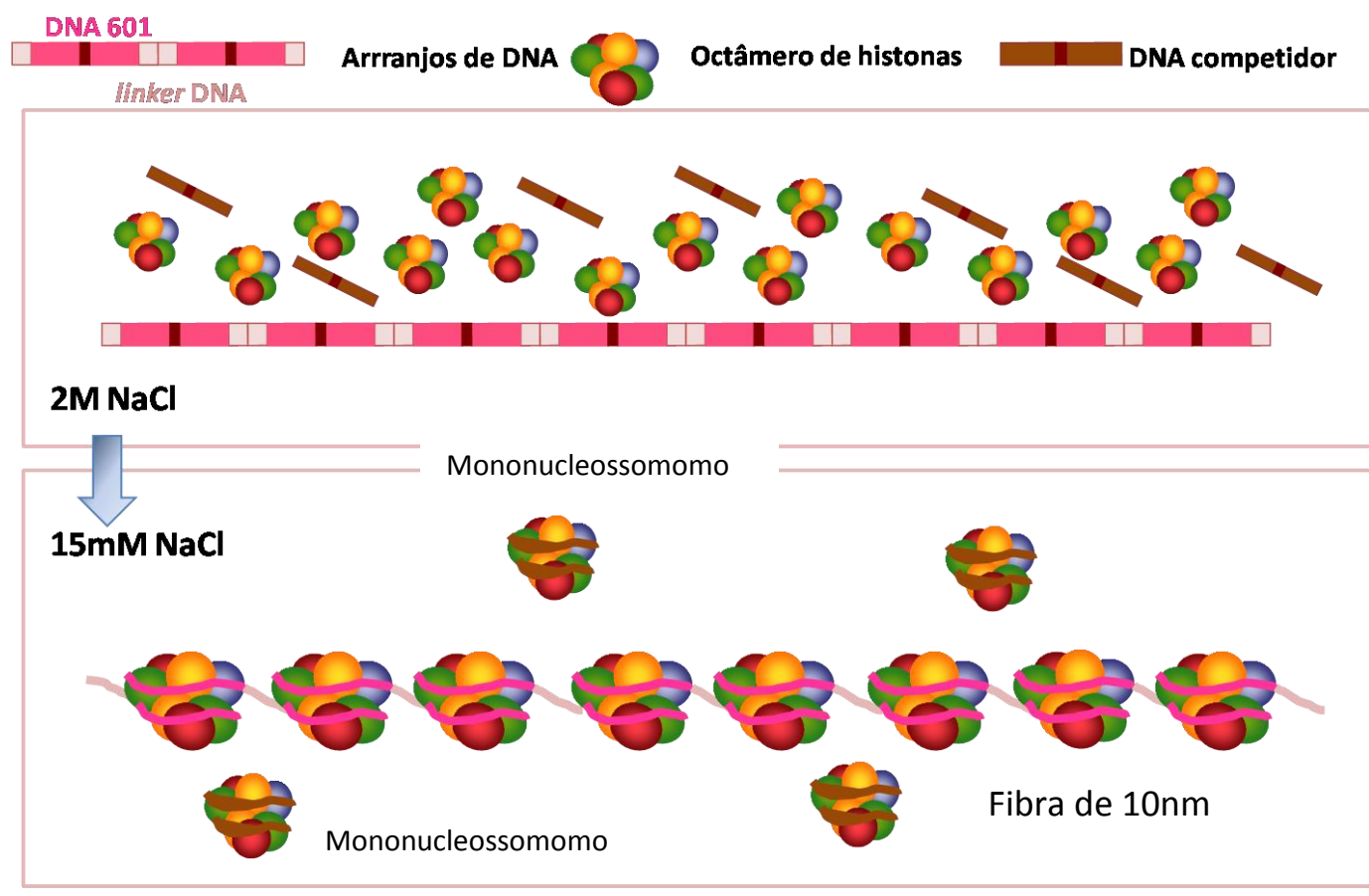

(a)

(b)

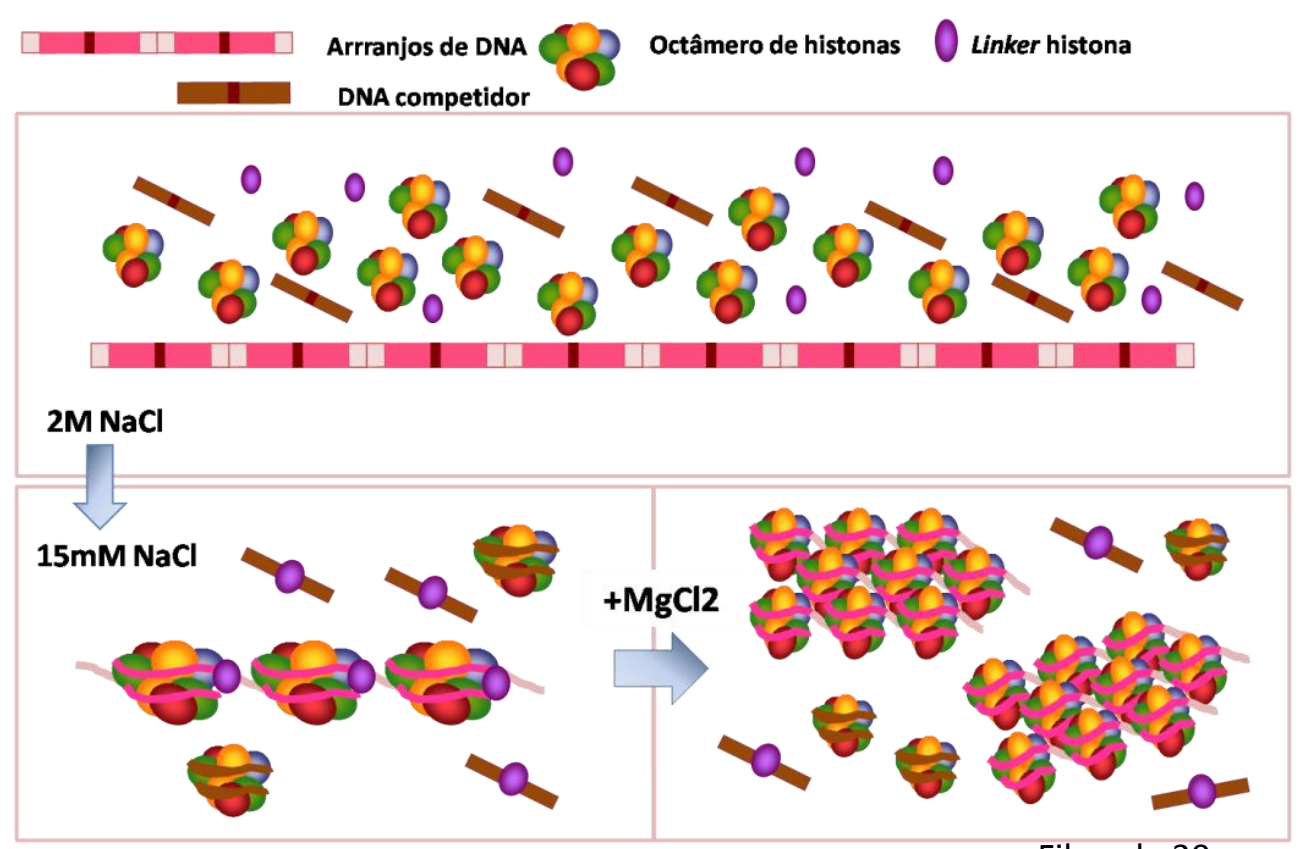

Fibra de 30nm

Figura 14. Ilustração da formação da fibra de $10 \mathrm{~nm}$ (a) e fibra de $30 \mathrm{~nm}$ (b).

(Desenho de Isabel Torres e Manuela Leite) 
Essa Figura 14 descreve o que ocorre durante a dialise lenta. Temos no final do processo uma ligação entre o DNA e o octâmero de histonas para formar o mononucleossomo ou a fibra de $10 \mathrm{~nm}$ ou a fibra de $30 \mathrm{~nm}$.

\subsection{2 - Mononucleossomo}

Para obtenção de mononucleossomos in vitro, adaptamos o protocolo acima elaborado por Rhodes e colaboradores (14).

Os tampões e os volumes totais de cada reação são os mesmos. Entretanto o arranjo do DNA colocado é o necessário para a formação do mononucleossomo, visto que o objetivo é formar monocleossomo e não a fibra. Também, aqui não é necessária a presença de DNA competidor. A mistura foi feita dentro de tubos de centrífuga siliconados de $(1,5 \mathrm{~mL})$, nesta ordem:

$>\operatorname{DNA}(167.1)$

> Tampão de em alta concentração de sal (2M NaCl, 10mM TEA-HCl pH7.4, $1 \mathrm{mM}$ EDTA)

$>$ Octâmero de histonas. A mistura foi transferida dentro o tubo de vidro para uma dialise lenta overnight a 4 graus. A análise foi feita por um gel de poliacrilimida $5 \%$

\subsubsection{Reconstituição do cromatossomo e tratamento com colesterol}

Para a reconstituição do cromatossomo, reproduzimos o protocolo previamente estabelecido por Tibor Gyuris (resultados não publicados), onde incubou-se a linker histona com mononucleossomo, previamente formado, por $1 \mathrm{~h}$ em $4^{\circ} \mathrm{C}$ (gelo).

Para os experimentos de cross-link, o complexo mononucleossomo:H5 foi incubado com glutaraldeído $0,1 \%$, por $20 \mathrm{~min}$ a temperatura ambiente $\left(25^{\circ} \mathrm{C}\right)$, antes de submeter o complexo à migração eletroforética em gel de acrilamida $5 \%$ corado com brometo de etídeo.

Após a determinação da concentração de H5 necessária para saturar o mononucleossomo, incubou-se o complexo com concentrações crescentes por $1 \mathrm{~h}$ a temperatura ambiente $\left(25^{\circ} \mathrm{C}\right)$. 


\subsubsection{Avaliação dos resultados}

A avaliação dos resultados foi feita por ensaio de mudança de migração electroforética utilizando géis de agarose $(0,8 \%)$ e poliacrilamida não desnaturante $(5 \%)$ preparados conforme ao protocolo usado no laboraorio de farmacologia molecular.O tampão de corrida foi o TBE 1X para o gel agarose e $0,5 \mathrm{X}$ para o gel de poliacrilamida 


\section{RESULTADOS}

\subsection{Digestão e purificação de plasmídeo para obtenção do fragmento DNA 601 - 167.1 (167 pares de base)}

4.1.1 Digestão do plasmídeo contendo a sequencia 167.80

Com o objetivo de realizar a reconstituição in vitro do mononucleossomo, primeiramente o plasmídeo pUC18, contendo uma sequência de um fragmento de DNA 601, 167.80, foi digerido utilizando a enzima AVA I. Na figura 15 observamos que a digestão do plasmídeo contendo o fragmento 167.80 foi realizada de forma satisfatória, gerando dois fragmentos com distintos tamanhos, 2659pb e 167 pb. A banda superior corresponde ao fragmento do esqueleto do plasmídeo, a banda inferior é o fragmento de interesse com 167 pb.

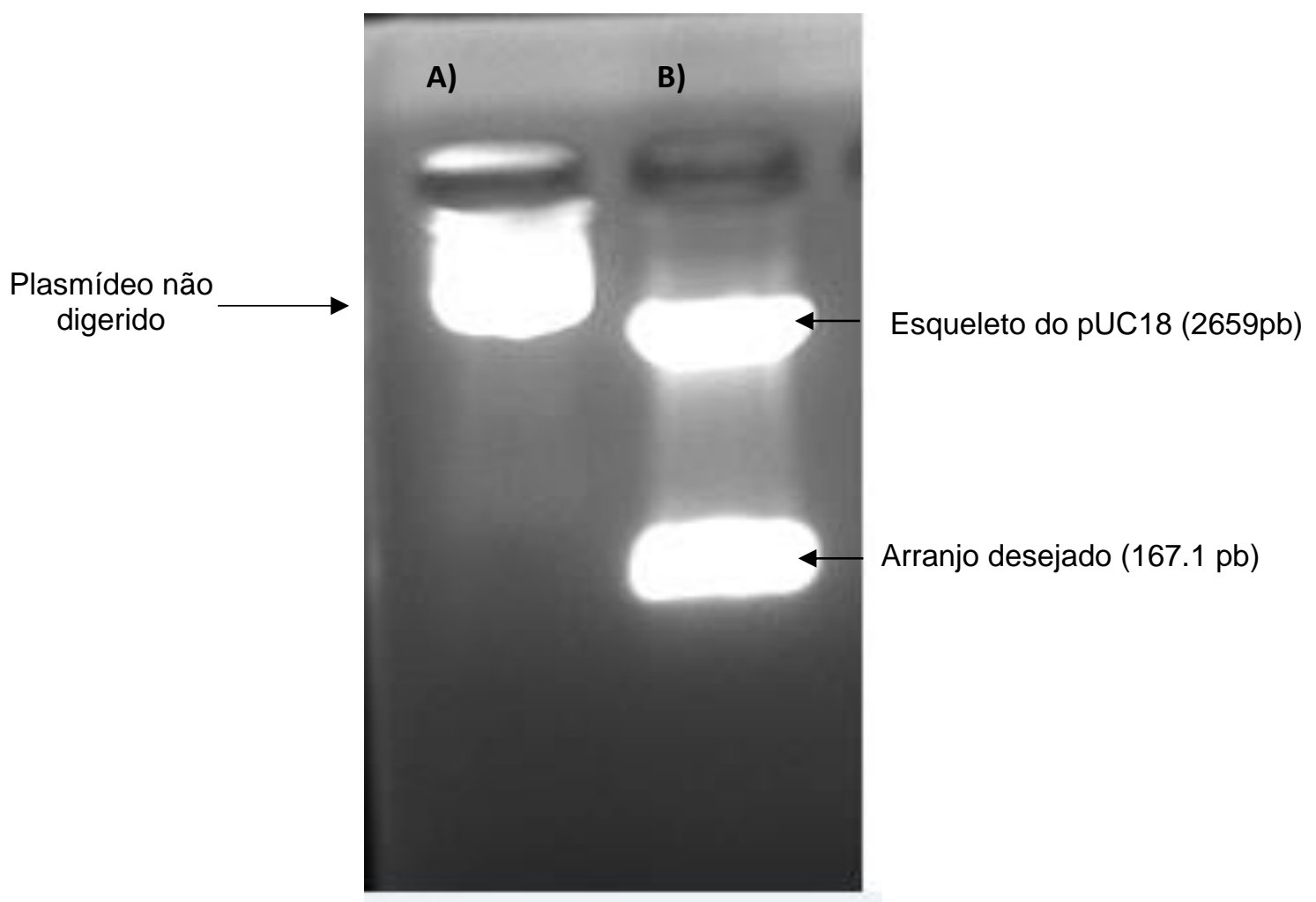

Figura 15: Digestão plasmidial com AVA I.

Gel de agarose 1\% corado com brometo de etídeo.

(A) plasmídeo sem digestão (B) plasmídeo digerido com AVA I. 


\subsubsection{Purificação do fragmento de DNA 601 - 167.1}

Para 0 isolamento do fragmento de interesse, após a digestão realizou-se a purificação do fragmento utilizando o método PEG 6000 (vide materiais e métodos) (Figura 16).

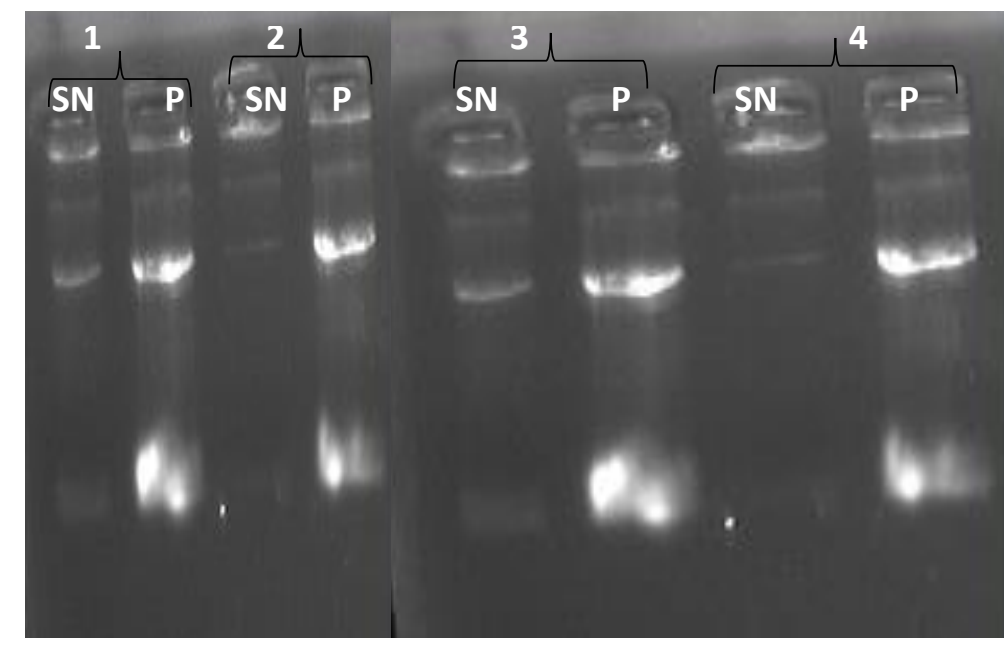

Figura 16. Precipitação de DNA com PEG.

Gel de agarose $1 \%$ corado com brometo de etídio. P: pellet; SN: sobrenadante. 1-4: adições sucessivas de $0,2 \%$ de PEG e centrifugações.

1-Primeira rodada: Adição de $2 \%$ do PEG 6000;incubalção 10Min no gelo, centrifugação a $4^{\circ} \mathrm{C}$ por 20 Min velocidade 13000rpm. Obtenção de um pellet $(P)$ e um sobrenadante (SN).O SN é transferido para um outro tube de centrifuga, o P é solubilizado com 100uL de água destilada. Em seguida, é corrido um gel de agarose $1 \%$ para avaliar o processo de purificação

2-Segunda rodada: Adição de $0,2 \%$ de PEG 6000 no SN (obtido em 1); incubação por $10 \mathrm{Min}$ no gelo,em seguida, centrifugação a $4^{\circ} \mathrm{C}$ por $20 \mathrm{Min}$ na uma velocidade de 13000rpm. Resultado :Obtenção de um pellet (P) e um sobrenadante (SN).Transferência do $\mathrm{P}$ para outro tubo.

$\begin{array}{lll}3-\text { terceira rodada usando } S N \text { do } & \text { 2) }+0,2 \% \mathrm{PEG} \text { em seguida, mesmo tratamento }\end{array}$ 
4-Quarta rodada :usando SN do 3) + 0,2\% PEG em seguida, mesmo tratamento

Após adição do PEG 6000 ate uma concentração final de 10\% (mais ou menos 50) o fragmento de 167.1 foi isolado com um excelente grau de pureza.

Posteriormente, o PEG foi então removido por fenol/clorofórmio (Figura 17).

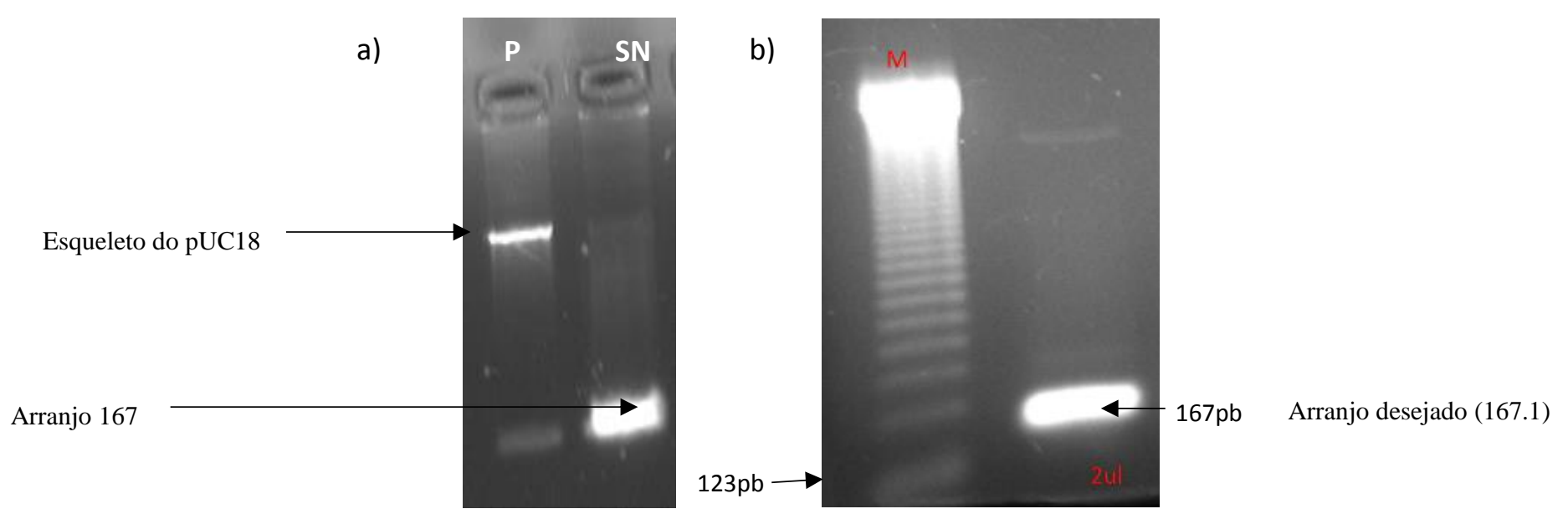

Figura 17: DNA purificado.

(a) Final da purificação com PEG. P: pellet contendo o esqueleto do plasmídeo. SN: sobrenadante contendo o fragmento 167.1. (b) Fragmento 167.1 após fenol-clorofórmio. M:marcadores do peso molecular

A figura 17 a) mostra o resultado da precipitação com o PEG 6000 .o esqueleto não desejável foi totalemente retirado e tem um peso molécular maior $(P)$.o SN apresenta a banda do fragmento desejável, como pode ser visto esse fragmento esta livre de impureza

Após o ultimo gel da precipitação com PEG 6000 (Fig.17.a),o SN contendo o fragmento desejável é purificado com fenol-clorofórmio no objetivo de limpar o DNA. Após esse tratamento com fenol-clorofómio, um gel de agarose $1 \%$ é corrido na presença de um marcador de peso molecular. Como pode ser observado, nosso fragmento tem exatamente $167 \mathrm{pb}$ e pronto para o uso. 


\subsection{Reconstituição in vitro do mononucleossomo}

Com o fragmento 167.1 purificado, realizou-se a reconstituição do mononucleossomo utilizando o octâmero de histonas $(\mathrm{HO})$ purificado de eritrócitos de galinha. A formação do mononucleossomo foi eficiente como mostrado na figura 18. Com a adição de concentrações crescentes de HO podemos notar a mudança de mobilidade eletroforética da banda de DNA, formando inicialmente uma segunda banda correspondente ao mononucleossomo. Concomitante ao aparecimento do mononucleossomo, observamos a diminuição de intensidade da banda do DNA livre, indicando a saturação do fragmento 167.1. Com uma quantidade de $20 \mathrm{uL}$ de $\mathrm{OH}$, aconteceu uma precipitação (ausência de banda), as quantidades de 12uL e 16uL favorecem uma melhor formação do mononucleossomo (consistência das respectivas bandas)

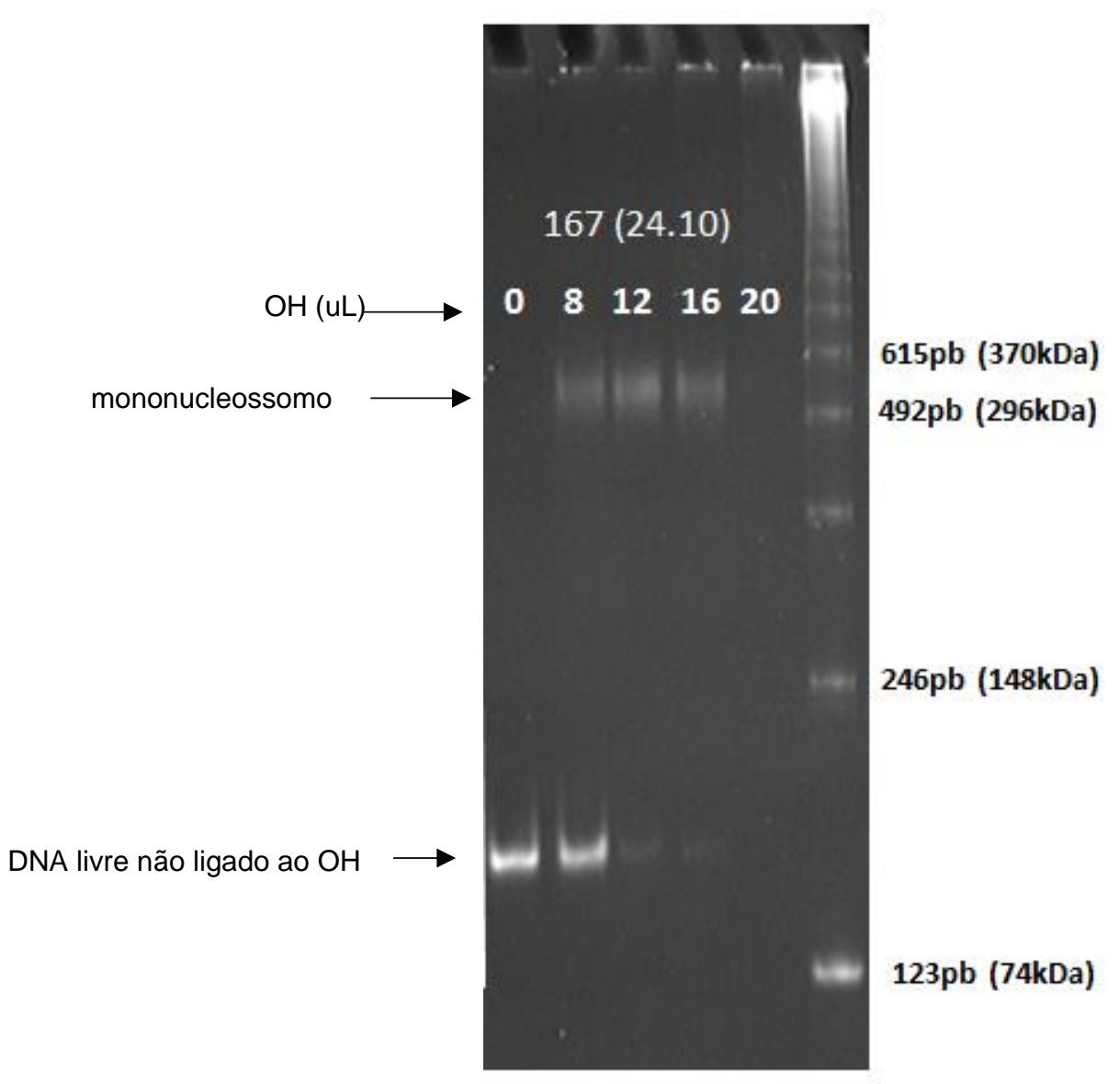

Figura18:Titulação de octâmero de histonas sobre o fragmento 167.1.

Gel de acrilamida 5\% corado com brometo de etídio. Observamos no gel o retardo na migração das bandas devido ao aumento de massa pela formação do mononucleossomo. 


\subsection{Etanol aumenta estabilidade do mononucleossomo reconstituído in vitro}

Para se observar o efeito do etanol sobre a cromatina, primeiramente incubamos mononucleossomo com concentrações crescentes de etanol $(0,5 \mathrm{M} ; 1 \mathrm{M} ; 1,5 \mathrm{M})$.

Conforme observamos na figura 19, as bandas com etanol (0.5 e 1M) estão mais fortes que as bandas do controle, mononucleossomo na ausência de etanol. Isto sugere que este agente desidratante aumenta a estabilidade do mononucleossomo. Importante observar que a concentração elevada de etanol $(1,5 \mathrm{M})$ induz a precipitação do mononucleossomo, observada pela ausência da banda. Vale ainda ressaltar que este gel não mostra a banda livre do DNA. A figura 19 mostra o resultado de uma incubação do mononucleossomo com 03 concentrações de etanol. Como pode ser visto, a banda teve uma melhor visibilidade com a concentração de $1 \mathrm{M}$, na presença de uma concentração de 1,5M, o mononucleossomo esta destruído (ausência de banda), estes resultados mostram o etanol aumenta a estabilidade do mononucleossomo ate uma concentração máxima de $1 \mathrm{M}$ 


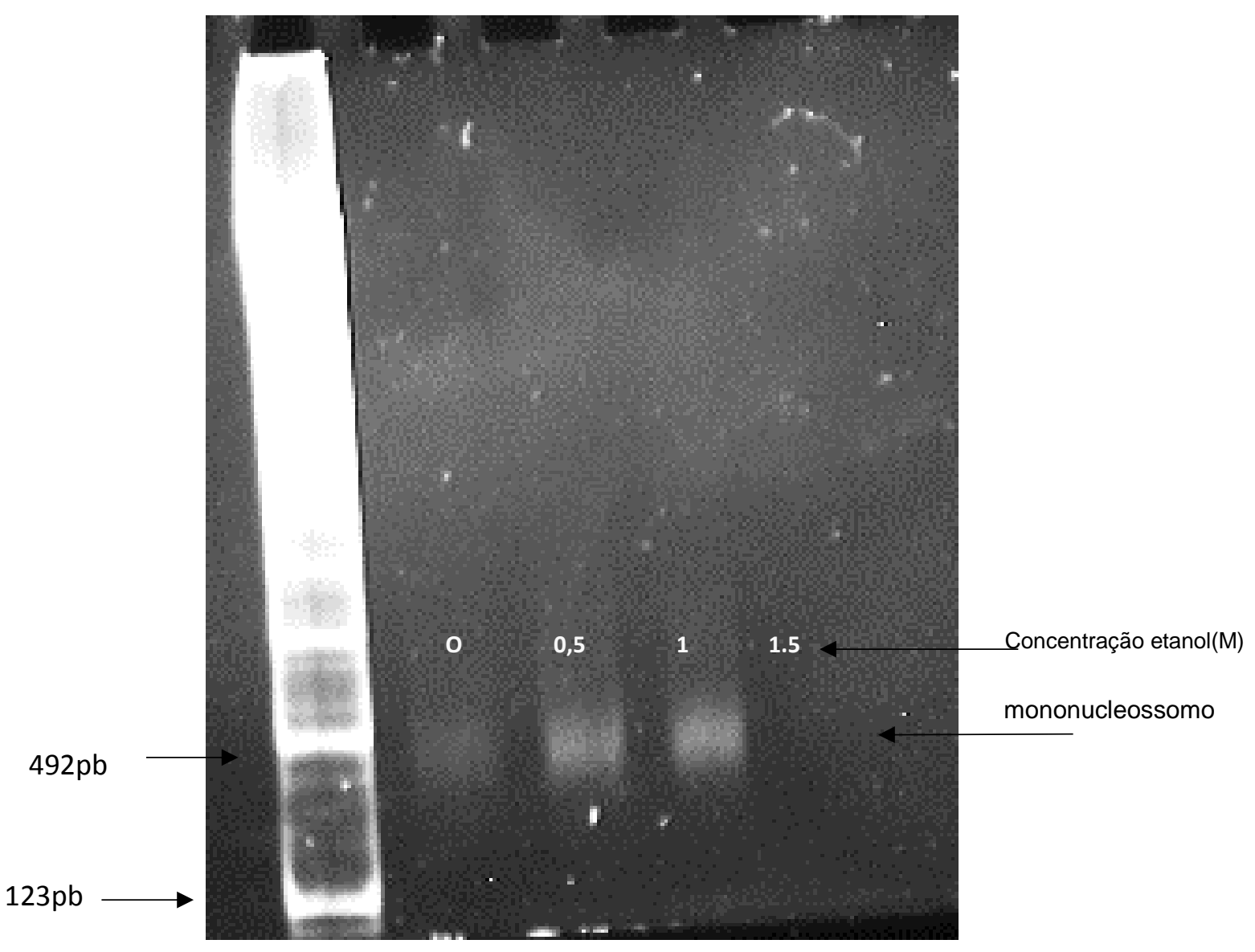

Figura 19: Incubação do mononucleossomo com etanol

Gel de acrilamida 5\% corado com brometo de etídeo. 0 - mononucleossomo controle (ausência de etanol), $0.5,1$, e $1.5 \mathrm{M}$ de etanol incubado com 0,4uM de mononucleossomo

Para se obter uma curva de saturação da concentração de etanol sobre o mononucleossomo, utilizou-se concentração menor de etanol $0,25 \mathrm{M}$, finalizando com a máxima de $1 \mathrm{M}$. O resultado se mostrou semelhante ao prévio ensaio, confirmando assim esse potencial efeito estabilizador do etanol sobre 0 mononucleossomo a $1 \mathrm{M}$ (Figura 20).Entres as 04 concentrações de etanol $(0,25 ; 0,5 ; 0.75 ; 1 \mathrm{M})$ a concentração de $1 \mathrm{M}$ favorece uma melhor visibilidade das bandas confirmando o resultado anterior que sugeriu um efeito positivo desta concentração sobre a estabilidade do mononucleossomo, entretanto, aqui observamos também a banda do DNA livre. Esse fenômeno sugere que este efeito aparente do etanol sobre o mononucleossomo possa ser somente artefato do ensaio, ou seja, o etanol melhora a visualização do DNA no gel corado com brometo de etideo. 


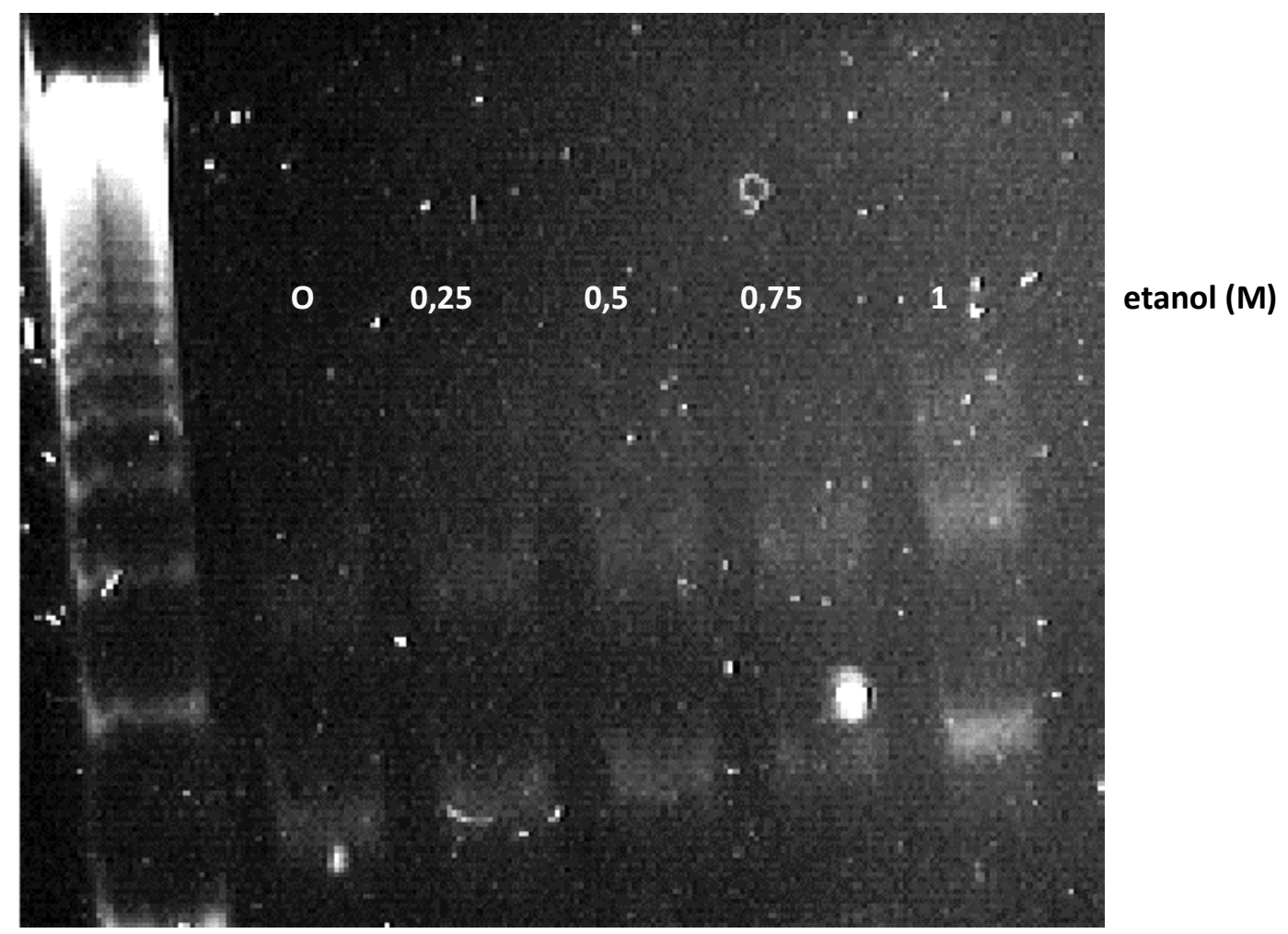

Figura 20: Saturação do mononucleossomo com $1 \mathrm{M}$ de etanol

Gel nativo de acrilamida 5\% corado com brometo de etídeo. 0 - mononucleossomo controle (ausência de etanol), 0.25, 0.5, 0.75 e $1 \mathrm{M}$ de etanol incubado com 0,4 uM de mononucleossomo

Para investigar este potencial artefato, um novo ensaio foi realizado incubando-se somente o DNA livre com etanol.

Podemos observar na figura 21 que o etanol parece prejudicar a visualização da banda do DNA na maior concentração (1M). Isto sugere que o etanol possa exercer um efeito especifico sobre o mononucleossomo.

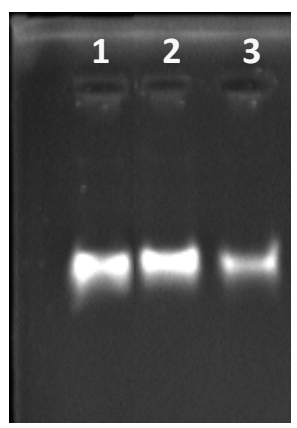

Figura 21. Efeito do etanol no DNA livre.

Gel de agarose 1\% corado com brometo de etídeo. Raia 1: DNA (1ug de 167.1) livre controle (ausência de etanol); raia 2: DNA livre incubado com 0,5M de etanol; raia 3: DNA livre incubado com $1 \mathrm{M}$ de etanol. 


\subsection{Efeito do etanol sobre a reconstituição de longas fibras de cromatina in vitro}

4.4 1. Etanol facilita a reconstituição in vitro de longas fibras de cromatina de $10 \mathrm{~nm}$

Para se observar o efeito do etanol sobre a formação de longas fibras de cromatina de 10nm in vitro (arranjos de DNA 601, 177.36), utilizou-se etanol em diferentes concentrações durante a reconstituição das fibras.

Observamos que o etanol possui a capacidade de antecipar o ponto de saturação do DNA 601 - 177.36. Conforme mostrado na figura 22, a mudança de mobilidade eletroforética da banda de DNA foi observada com $18 \mu \mathrm{L}$ de octamero de histonas, quando em presença de etanol a $0.1 \mathrm{M}$ esta banda com maior peso molecular foi observada com $9 \mu \mathrm{L}$ de $\mathrm{OH}$. 


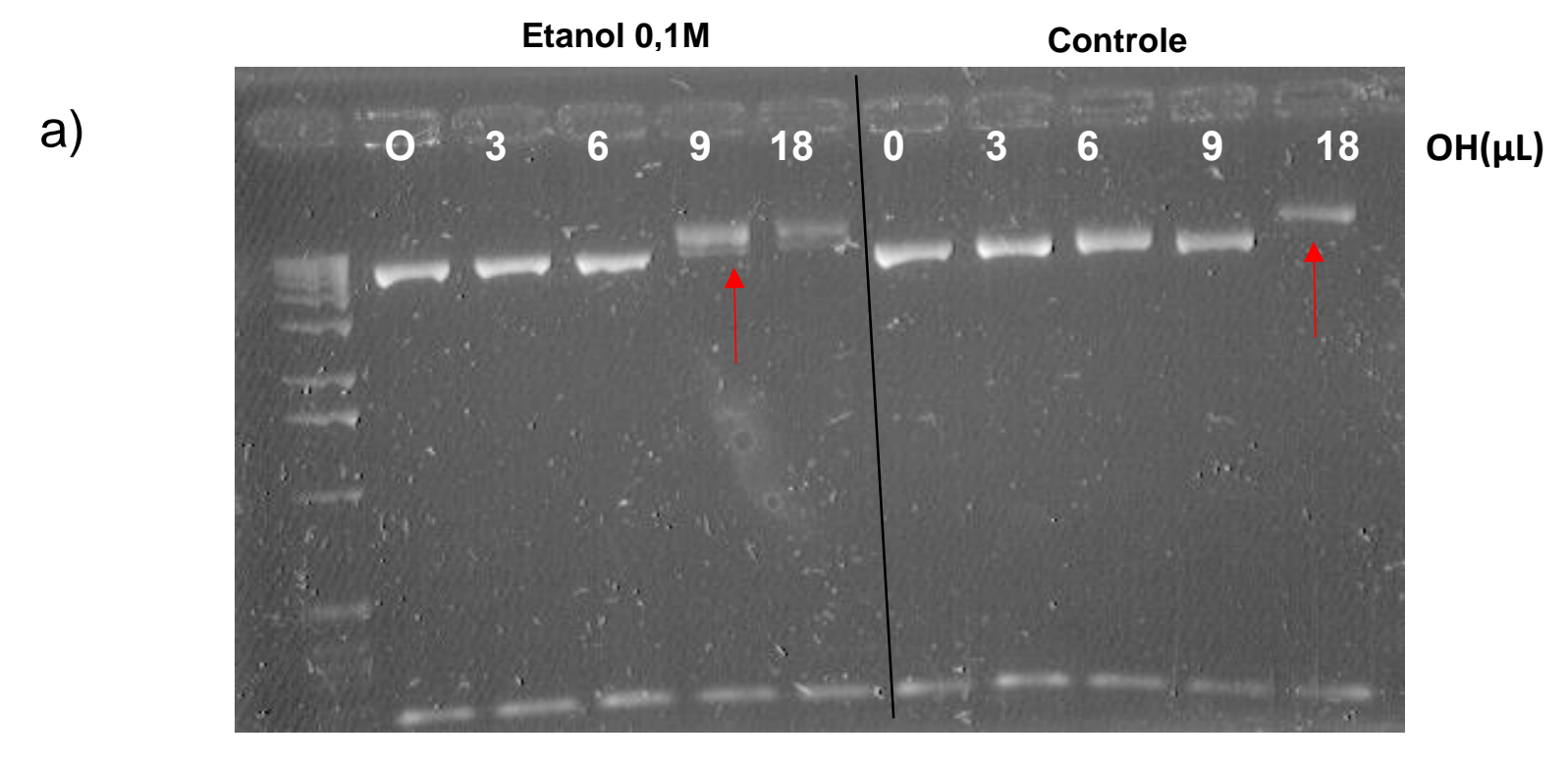

b)

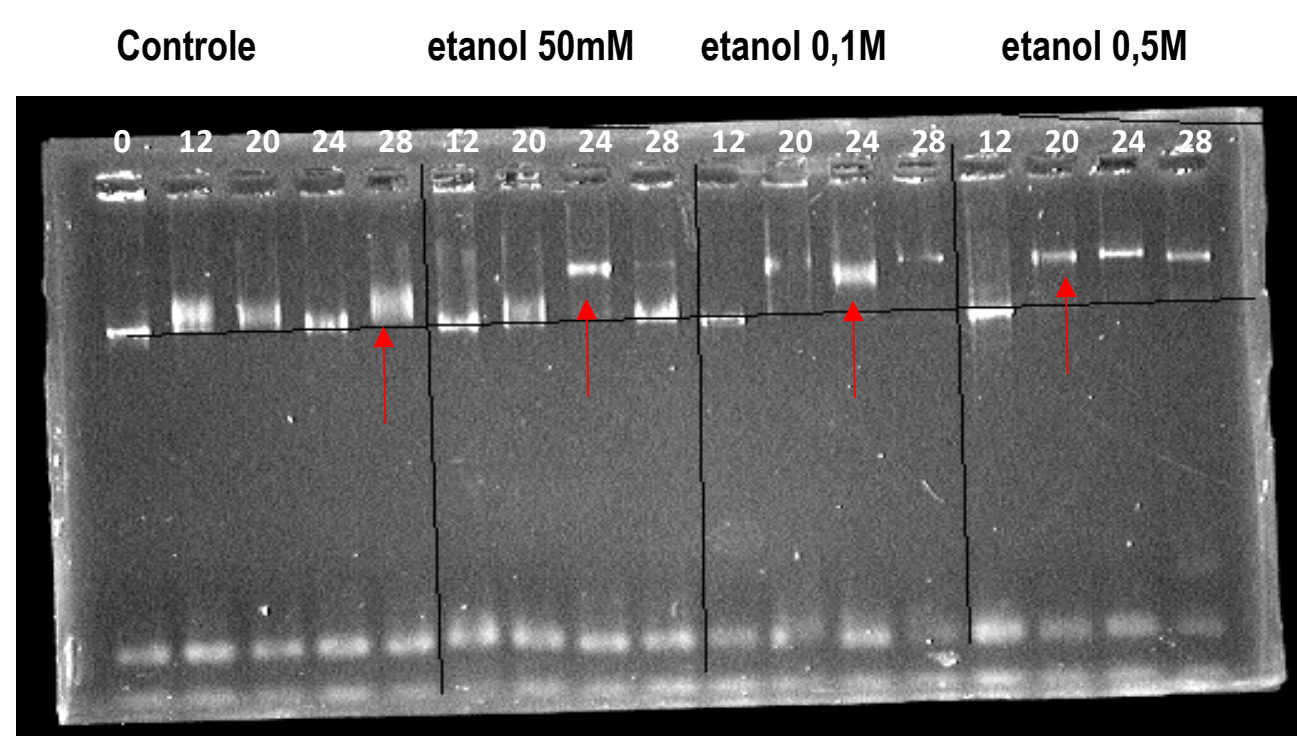

$H O(\mu L)$

Figura 22: Reconstituição da fibra de cromatina de $10 \mathrm{~nm}$ na presença e na ausência de etanol. Gel de agarose 0,8\% corado com brometo de etídeo. a) Reconstituição de fibras de cromatina controle e com $0,1 \mathrm{M}$ etanol. b) Reconstituição de fibras de cromatina 177.36 controle e na presença de concentrações crescentes de etanol (50mM; 0,1M; $0,2 \mathrm{M})$. 


\subsubsection{Etanol não apresenta efeito sobre a reconstituição in vitro de fibras de cromatina de $30 \mathrm{~nm}$}

Para se observar o efeito do etanol sobre a formação de fibras de $30 \mathrm{~nm}$ de cromatina, realizou-se a reconstituição in vitro com o arranjo 177.36 em presença de $0.1 \mathrm{M}$ de etanol.

A formação das fibras de $30 \mathrm{~nm}$ in vitro se inicia com $12 \mu \mathrm{L}$ de $\mathrm{H} 5$, chegando a máxima compactação com $14 \mu \mathrm{L}$ de $\mathrm{H} 5$, observada pela troca de mobilidade da banda de DNA (estrutura mais compactada e migrando mais no gel de agarose) (Figura 23a). Quando em presença de etanol (Figura 23b), observamos, apesar da baixa resolução da imagem e qualidade do gel, que o inicio da compactação da fibra de $30 \mathrm{~nm}$ também ocorreu com $12 \mu \mathrm{L}$ de $\mathrm{H} 5$ e que a máxima aconteceu com $14 \mu \mathrm{L}$ de H5. Estes resultados sugerem que o etanol não altera a reconstituição das fibras de cromatina in vitro.

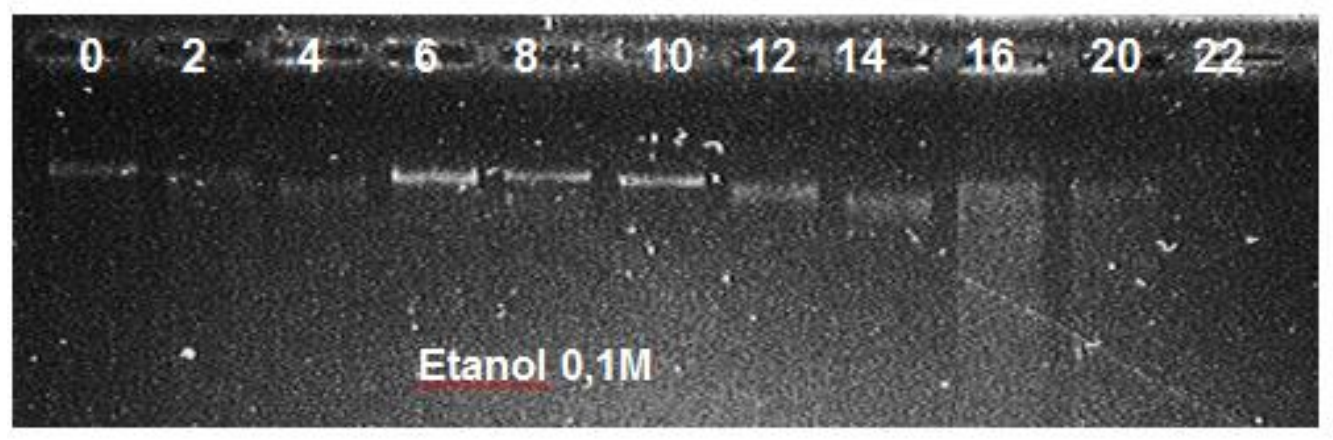

$\mathrm{H} 5(\mu \mathrm{l})$

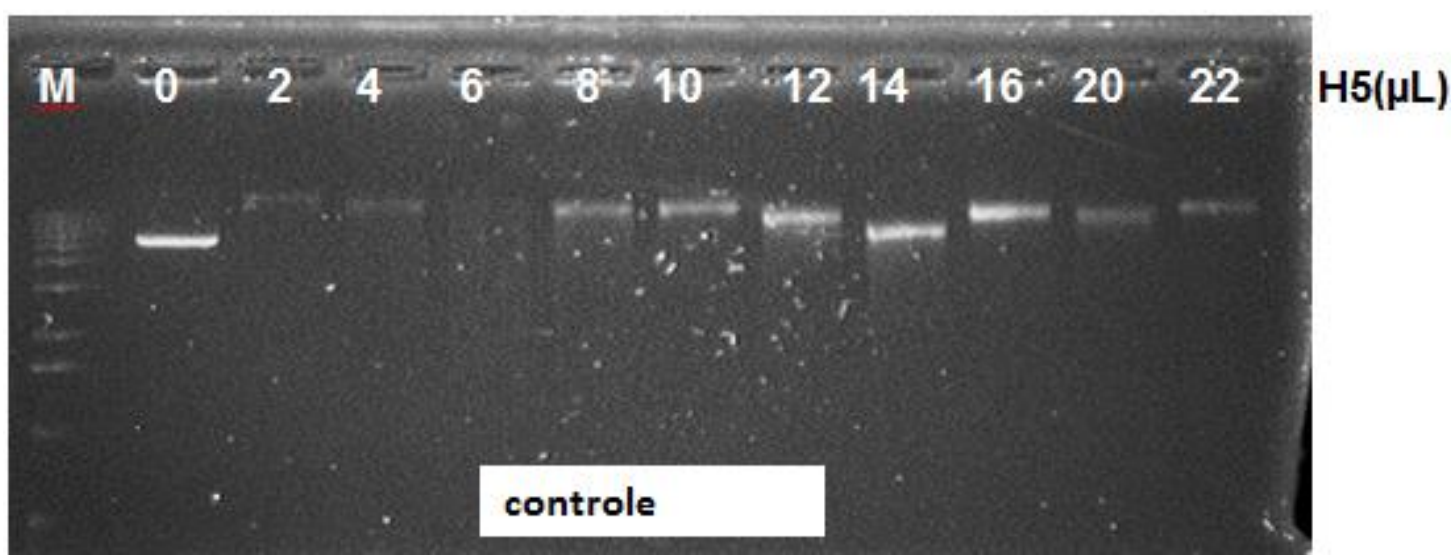

Figura 23. Reconstituição da Fibra de 30nm em presença e ausência de etanol.

Gel agarose $0,8 \%$ corado com brometo de etídeo.Titulação de H5 sobre os arranjos $177.36 \mathrm{em}$ presença de $01 \mathrm{M}$ de etanol. 0 , controle na ausência de H5 (fibra de 10nm), 2-22 $\mu \mathrm{L}$ de H5 na reconstituição das fibras de cromatina de 30nm.M:macardore de peso molecular 


\subsubsection{Colesterol estabiliza a formação do cromatossoma in vitro}

Conforme observado em meados de junho de 2014, em prévios ensaios realizados por um colega do grupo, pós-doutorando Tibor Gyuris (resultados não publicados), o colesterol parece possuir um efeito estabilizador sobre 0 cromatossoma, complexo mononucleossomo: H5, reconstituído in vitro. Desta forma, para se determinar a concentração ideal do colesterol para exercer este efeito estabilizador sobre o cromatossoma, o nucleossomo reconstituído in vitro foi incubado com H5 e colesterol, conforme descrito no Material e Métodos (5.3).

Conforme previamente observado, uma pequena mudança de migração eletroforética acontece em presença da linker histona, sugerindo a formação do cromatossomo (Figura 24 - controle). Em presença do colesterol, observamos uma mudança de mobilidade eletroforética, da banda correspondente ao mononucleossomo, ainda mais acentuada. Além disto, estas bandas se apresentam mais robusta, sugerindo a melhor formação do cromatossoma. Observamos também que o colesterol induziu o desaparecimento da banda do DNA livre, sugerindo que colesterol promoveu a precipitação do DNA livre ou ainda que o colesterol promoveu o deslocamento de equilíbrio para a formação dos novos cromatossomas in vitro.

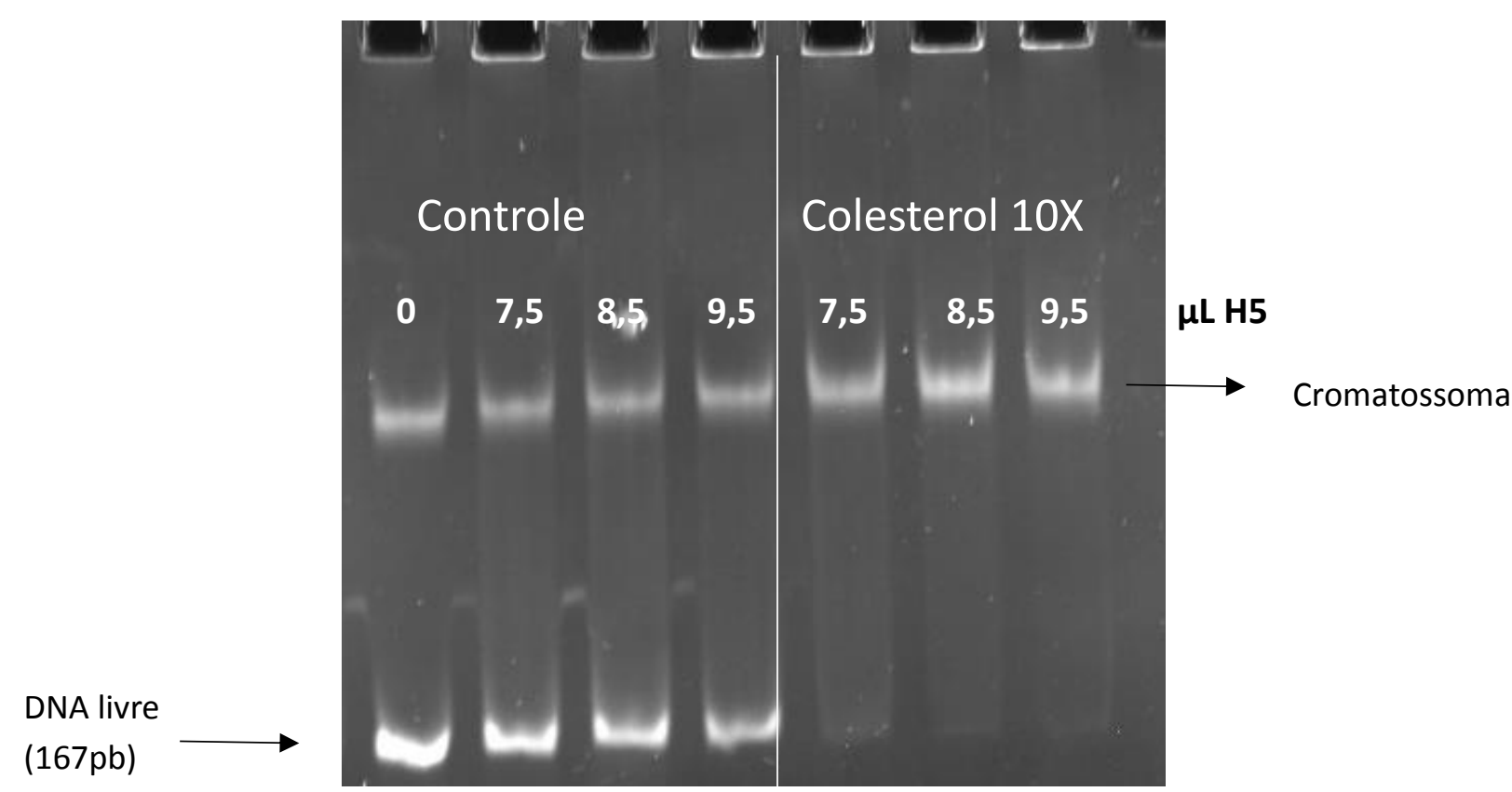

Figura 24. Reconstituição do cromatossomo em ausência e presença de colesterol 10X. Gel de acrilamida $6 \%$ corado com brometo de etídio. Mononucleossomo 0,4uM reconstituídos in vitro foi incubados com volumes crescentes de H5 de concentração 1,5uM. 
Para a obtenção de um melhor complexo mononucleossomo:H5, o cromatossomo, e observar a ação do colesterol sobre a fibra este complexo, novos ensaios foram realizados utilizando um crosslinker gluteraldeído $(0,1 \%$ do volume total da reação) para estabilizar o complexo. Observamos na figura 25 que nas condições de crosslink utilizadas, este causou a precipitação do cromatossoma desistabilização e precipitação do complexo tanto na ausência como na presença de colesterol. Além disso podemos confirmar que o colesterol ajuda na formação do complexo uma vez que a banda correspondente ao cromatossomo aparece de forma mais clara na presença de colesterol.

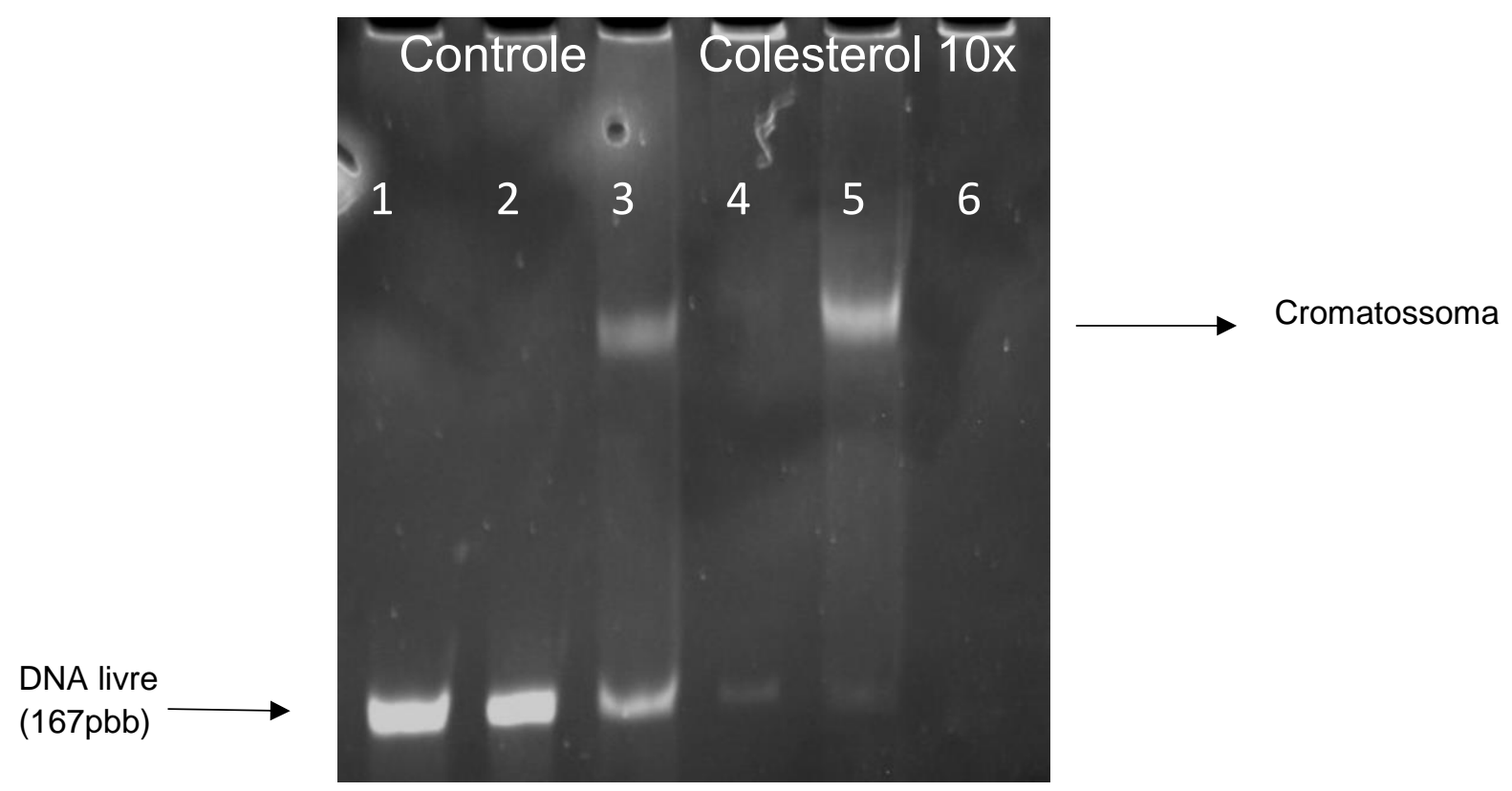

Figura 25. Crosslink do Cromatossoma com gluteraldeido $5 \%$ em ausência e presença de colesterol. Gel de acrilamida 5\% corado com brometo de etídeo. Raia 1: DNA livre sem crosslink. Raia 2: DNA livre com crosslink. Raia 3: Cromatossomo controle (ausência de colesterol) sem crosslink. Raia 4: Cromatossomo controle (ausência de colesterol) com crosslink. Raia 5: Cromatossomo incubado com colesterol 10x sem crosslink. Raia 6: Cromatossomo incubado com colesterol 10x) com crosslink 


\section{DISCUSSÃO}

Desvendar o mecanismo dinâmico de compactação da cromatina é ainda um grande desafio para os biólogos. Sabemos que diversos fatores contribuem para a modulação da arquitetura da cromatina, tais como, presença de modificações póstraducionais em caudas de histonas (24), proteínas remodeladoras da cromatina dependentes de ATP e concentração de íons divalentes(51) e troca de variantes de histonas (52). Além destes, proteínas ligantes de nucleossomo, conhecidas com Nucleosome Binding Proteins, exercem um papel crucial para modulação da cromatina e desfecho transcricional (53). Assim, qualquer composto químico com habilidade de alterar a ligação destes fatores ao nucleossomo ou modificação das cargas das caudas das histonas possui grande potencial para regular a transcrição e mecanismos responsáveis pela manutenção do genoma.

O estudo estrutural da cromatina para a compreensão de sua fisiologia ainda apresenta desafios que até o momento não foram vencidos. Fibras de cromatina extraídas de células cultivadas em laboratório apresentam uma enorme variabilidade do espaçamento e posição dos nucleossomos. Além disto, as fibras de cromatina extraídas in vivo apresentam uma grande heterogeneidade na composição proteica da partícula central do nucleossomo, com diversas histonas variantes, e proteínas ligadoras de nucleossomo (Nucleosome Binding Proteins). Uma estratégia desenvolvida para contornar esta dificuldade é a reconstituição de fibras de cromatina in vitro (50). Utilizando a sequencia de DNA com forte posicionamento de nucleossomos e histonas purificadas de eritrócitos de galinha, podemos melhor compreender a dinâmica das fibras de cromatina e assim dissecar as interações intra e internucleossomais, sem a interferência de outros fatores, como, por exemplo, proteínas ligantes de nucleossomo e variações na concentração de íons.

Apesar de já termos uma metodologia bem estabelecida para obtenção das longas fibras de cromatina e mononucleossomos, a otimização desta técnica se faz necessária para se obter amostras em concentrações suficientes e de boa qualidade para realização de estudos estruturais.

Desta forma, uma das linhas de pesquisa do grupo da nossa equipe foca na identificação de moléculas que ligam ao nucleossomo, como detergentes, etanol e 
lipídeos, para aumentar a estabilidade de fibras de cromatina e mononucleossomos reconstituídos in vitro.

Após um longo período trabalhando na digestão e purificação do fragmento de DNA 601, conseguimos estabelecer um protocolo reproduzível para as diferentes etapas da reconstituição do mononucleossomo in vitro. Mais importante, estabelecemos aqui a metodologia para a reconstituição do mononucleossomo a partir de DNA 601 e $\mathrm{OH}$ extraído de eritrócitos de galinha. Desta forma, ao nosso conhecimento, somos os primeiros a realizar este procedimento no Brasil.

Com o objetivo de se obter melhores amostras de mononucleossomo para estudos estruturais, realizamos a análise do efeito desidratante do etanol sobre o mononucleossomo. Resultados preliminares obtidos pela doutoranda Isabel Torres em nosso grupo indicam que o etanol possa ter um efeito protetor ou estabilizador sobre o mononucleossomo. Aqui, através de ensaios bioquímicos, sugerimos que o etanol, em concentração máxima de $1 \mathrm{M}$, possui a capacidade de estabilizar o mononucleossomo formado in vitro.

A principal hipótese para explicar este efeito estabilizador do etanol sobre o mononucleossomo é que na presença de moléculas de etanol ocorre a desidratação do complexo (octâmero de histona e DNA), promovendo o deslocando moléculas de água e aumentando as interações entre o DNA e as histonas. Entretanto há a possibilidade de que o etanol está simplesmente impedindo a perda de histonas que no momento de pipetar pode se ligar nas ponteiras e nos tubos devido a sua carga altamente positiva.

Esse resultado é importante para futuros estudos estruturarias (microscopia, cristalografia etc..).Ele mostra que a utilização do etanol pode favorecer a obtenção das amostras de mononucleossomo com melhor estabilidade e concentração ;fatores indispensáveis para os estudos citados acima

Sobre as fibras de cromatina, observamos que o etanol promove a antecipação do ponto de saturação do arranjo de DNA 601 pelo HO para formação da fibra de 10nm. É interessante observar que este efeito não foi observado sobre a formação da fibra de $30 \mathrm{~nm}$, ou seja, apesar do efeito sobre a fibra de $30 \mathrm{~nm}$, o etanol não auxiliou a H5 na compactação da fibra de 10nm. Estes resultados são de 
grande valor pois podem auxiliar no desenvolvimento de novas metodologias para obtenção de longas fibras de cromatina para estudos estruturais.

Conforme mencionado anteriormente, nosso grupo também estuda a ação do colesterol sobre a formação das fibras de 10 e $30 \mathrm{~nm}$ in vitro. Resultados obtidos, mas ainda não publicados, pela doutoranda Isabel Torres sugerem que o colesterol auxilia a formação da fibra de 30nm. Assim, com o objetivo de analisar a influência do colesterol sobre a ligação da H5 as fibras de cromatina, iniciamos novos ensaios de reconstituição do cromatossoma in vitro. Os resultados obtidos por Tibor Gyuris, pós-doutorando do grupo do Professor Guilherme Santos, sugerem que o colesterol auxilia a formação do cromatossomo, antecipando o ponto de saturação e evitando a precipitação do complexo mono: H5, o cromatossoma (resultados não publicados). Assim, iniciei novos ensaios com o objetivo de determinar a concentração ideal de colesterol capaz de exercer este efeito estabilizador sobre o cromatossoma. Mostramos que o colesterol, concentração 10X, induziu a formação do mononucleossomo e o desaparecimento da banda do DNA livre. Estes resultados sugerem que colesterol promove o deslocamento do equilíbrio para a formação do novos cromatossomas in vitro, apesar desta reação ter acontecido em fase anterior. Entretanto devemos considerar que o colesterol esteja agindo sobre o DNA livre de forma inespecífica, fazendo com que este forme estruturas grandes o que facilitaria a precipitação.

Nossos resultados demostram fenômenos in vitro que possam estar acontecendo no ambiente celular, entretanto precisamos ainda realizar novos ensaios baseado em cultura de célula para analisar o efeito destes agentes desidratantes sobre a cromatina. De qualquer forma, nos permitimos aqui discutir o impacto fisiológico que nossos resultados podem apresentar. Caso o efeito estabilizador do etanol sobre o nucleossomo seja observado in vivo, esperamos uma mudança da expressão genica global, devido ao aumento da rigidez do nucleossomo, que se tornaria uma barreira ainda mais forte para impedir o processo transcricional.

Observamos também que o colesterol induz a formação do cromatossoma e facilita a formação da fibra de 30nm. Desta forma, é possível esperar que colesterol 
promova a repressão genica dependente da concentração de linker histona, $\mathrm{H} 1$ ou H5.

Acima de tudo, mostramos que pequenas moléculas de grande relevância fisiológica, como o etanol e colesterol, afetam diretamente a dinâmica de fibras de cromatina in vitro. Mas será que este fenômeno observado in vitro será observado in vivo? Novos estudos estão sendo realizados para responder tais perguntas. 


\section{6 .CONLUSÃO}

1) Foi possível estabelecer o metodologia para reconstituição do mononucleossomos, de cromatossoma e fibras de cromatina.

2) O etanol auxilia a formação do mononucleossomo e fibras de cromatina de $10 \mathrm{~nm}$.

3) O colesterol auxilia a formação do cromatossoma in vitro em uma concentração de $10 \mathrm{X}(11,6 \mu \mathrm{M})$, sendo este o potencial mecanismo para aumentar a estabilidade das fibras de $30 \mathrm{~nm}$.

Finalmente, mostramos que nossos resultados possuem grande relevância bioquímica e estrutural. Não sabemos ainda da relevância fisiológica destes achados, entretanto abrimos aqui um caminho para se investigar o efeito destes agentes sobre a cromatina no ambiente celular. 


\section{PERSPECTIVAS}

Em um futuro próximo, o grupo do Professor Santos pretende investigar com mais detalhes os efeitos do etanol sobre a fibra de $30 \mathrm{~nm}$, utilizando-se outros arranjos de DNA 601.

Será importante também determinar a concentração mínima de colesterol que pode afetar a formação do cromatossoma in vitro.

Além das observações in vitro, o grupo está realizando trabalhos baseados em células de mamíferos para avaliar a relevância fisiológica do etanol e colesterol sobre a cromatina. 


\section{REFERÊNCIAS}

1. Luger K, Collins F. Nucleosomes : Structure and Function. 2001;1-8.

2. Richmond RK, Sargent DF, Richmond TJ, Luger K, Ma AW. Crystal structure of the nucleosome ${ }^{\circ}$ resolution core particle at 2 . 8 A. 1997;7:251-60.

3. Richmond RK, Sargent DF, Richmond TJ, Luger K, Mader AW. Crystal structure of the nucleosome core particle at 2.8 Aresolution. Nature. 1997;389.

4. Richmond TJ, Davey $\mathrm{C}$ a. The structure of DNA in the nucleosome core. Nature [Internet]. 2003 May 8;423(6936):145-50. Available from: http://www.ncbi.nlm.nih.gov/pubmed/12736678

5. Khorasanizadeh S. The Nucleosome : From Genomic Organization to Genomic Regulation. Cell. 2004;116:259-72.

6. Adenot PG, Campion E, Legouy E, Allis CD, Dimitrov S, Renard J, et al. Somatic linker histone $\mathrm{H} 1$ is present throughout mouse embryogenesis and is not replaced by variant $\mathrm{H} 1^{\circ}$. 2000;2907:2897-907.

7. Tóth K, Brun N, Langowski J. Chromatin compaction at the mononucleosome level. Biochemistry [Internet]. 2006 Feb 14;45(6):1591-8. Available from: http://www.ncbi.nlm.nih.gov/pubmed/16460006

8. Vignali M, Workman JL. Location and function of linker histones. Nat Struct Biol [Internet]. 1998 Dec;5(12):1025-8. Available from: http://www.nature.com/doifinder/10.1038/4133

9. Routh A, Sandin S, Rhodes D. Nucleosome repeat length and linker histone stoichiometry determine chromatin fiber structure. Proc Natl Acad Sci U S A [Internet]. 2008 Jul 1;105(26):8872-7. Available from: http://www.pubmedcentral.nih.gov/articlerender.fcgi?artid=2440727\&tool=pmce ntrez\&rendertype $=$ abstract

10. Song F, Chen P, Sun D, Wang M, Dong L, Liang D, et al. Cryo-EM Study of the Chromatin Fiber Tetranucleosomal Units. 2014;(April):376-81.

11. Jenuwein T, Allis CD. Translating the histone code. Science [Internet]. 2001 Aug 10 [cited 2013 Nov 6];293(5532):1074-80. Available from: http://www.ncbi.nlm.nih.gov/pubmed/11498575

12. Dorigo B, Schalch T, Bystricky K, Richmond TJ. Chromatin Fiber Folding: Requirement for the Histone H4 N-terminal Tail. J Mol Biol. 2003 Mar;327(1):85-96.

13. Clark DJ, Kimura T. Electrostatic mechanism of chromatin folding. J Mol Biol. 1990 Feb;211(4):883-96. 
14. Huynh $\vee$ a T, Robinson PJJ, Rhodes D. A method for the in vitro reconstitution of a defined " $30 \mathrm{~nm}$ " chromatin fibre containing stoichiometric amounts of the linker histone. J Mol Biol [Internet]. 2005 Feb 4 [cited 2013 Dec 2];345(5):95768. Available from: http://www.ncbi.nlm.nih.gov/pubmed/15644197

15. Schalch T, Duda S, Sargent DF, Richmond TJ. X-ray structure of a tetranucleosome and its implications for the chromatin fibre. Nature [Internet]. 2005 Jul 7 [cited 2014 Dec 15];436(7047):138-41. Available from: http://www.ncbi.nlm.nih.gov/pubmed/16001076

16. Felsenfeld G, Groudinet M. The digital code of DNA. Nature [Internet]. 2003 Jan 23 [cited 2014 Jul 12];421(6921):444-8. Available from: http://www.ncbi.nlm.nih.gov/pubmed/12540920

17. Finch JT, Klug a. Solenoidal model for superstructure in chromatin. Proc Natl Acad Sci U S A [Internet]. 1976 Jun;73(6):1897-901. Available from: http://www.pubmedcentral.nih.gov/articlerender.fcgi?artid=430414\&tool=pmcen trez\&rendertype=abstract

18. Worcel A, Strogatzt S, Rileyt D. Structure of chromatin and the linking number of DNA. PNAS. 1981;78(3):1461-5.

19. Robinson PJJ, Fairall L, Huynh V a T, Rhodes D. EM measurements define the dimensions of the "30-nm" chromatin fiber: evidence for a compact, interdigitated structure. Proc Natl Acad Sci U S A [Internet]. 2006 Apr 25;103(17):6506-11. Available from:

http://www.pubmedcentral.nih.gov/articlerender.fcgi?artid=1436021\&tool=pmce ntrez\&rendertype=abstract

20. Widom J. AND FUNCTION OF CHROMATIN IN VITRO. 1998;285-327.

21. Cosgrove MS, Boeke JD, Wolberger C. Regulated nucleosome mobility and the histone code. Nat Struct Mol Biol [Internet]. 2004 Nov [cited 2015 Jun 24];11(11):1037-43. Available from:

http://www.ncbi.nlm.nih.gov/pubmed/15523479

22. Jin J, Cai Y, Li B, Conaway RC, Workman JL, Conaway JW, et al. In and out: histone variant exchange in chromatin. Trends Biochem Sci [Internet]. 2005 Dec [cited 2015 Jun 24];30(12):680-7. Available from: http://www.ncbi.nlm.nih.gov/pubmed/16257529

23. Saha A, Wittmeyer J, Cairns BR. Chromatin remodelling: the industrial revolution of DNA around histones. Nat Rev Mol Cell Biol [Internet]. 2006 Jun [cited 2015 Apr 27];7(6):437-47. Available from: http://www.ncbi.nlm.nih.gov/pubmed/16723979

24. Sadakierska-Chudy A, Filip M. A comprehensive view of the epigenetic landscape. Part II: Histone post-translational modification, nucleosome level, and chromatin regulation by ncRNAs. Neurotox Res [Internet]. 2015 Feb [cited 2015 Jun 24];27(2):172-97. Available from: 
http://www.pubmedcentral.nih.gov/articlerender.fcgi?artid=4300421\&tool=pmce ntrez\&rendertype=abstract

25. Cohen I, Poręba E, Kamieniarz K, Schneider R. Histone modifiers in cancer: friends or foes? Genes Cancer [Internet]. 2011 Jun [cited 2015 Jun 24];2(6):631-47. Available from:

http://www.pubmedcentral.nih.gov/articlerender.fcgi $?$ artid=3174261\&tool=pmce ntrez\&rendertype=abstract

26. Kouzarides T. Chromatin modifications and their function. Cell [Internet]. 2007 Feb 23 [cited 2014 Mar 19];128(4):693-705. Available from:

http://www.ncbi.nlm.nih.gov/pubmed/17320507

27. Ropero S, Esteller M. The role of histone deacetylases (HDACs) in human cancer. Mol Oncol [Internet]. 2007 Jun [cited 2014 Dec 3];1(1):19-25. Available from: http://www.ncbi.nlm.nih.gov/pubmed/19383284

28. Kalashnikova A a, Porter-Goff ME, Muthurajan UM, Luger K, Hansen JC. The role of the nucleosome acidic patch in modulating higher order chromatin structure. J R Soc Interface [Internet]. 2013 May 6;10(82):20121022. Available from:

http://www.pubmedcentral.nih.gov/articlerender.fcgi $?$ artid=3627075\&tool=pmce ntrez\&rendertype=abstract

29. Shakespear MR, Halili M a, Irvine KM, Fairlie DP, Sweet MJ. Histone deacetylases as regulators of inflammation and immunity. Trends Immunol [Internet]. 2011 Jul [cited 2015 May 18];32(7):335-43. Available from: http://www.ncbi.nlm.nih.gov/pubmed/21570914

30. Nebbioso A, Clarke N, Voltz E, Germain E, Ambrosino C, Bontempo P, et al. Tumor-selective action of HDAC inhibitors involves TRAIL induction in acute myeloid leukemia cells. Nat Med [Internet]. 2005 Jan [cited 2015 May 14];11(1):77-84. Available from:

http://www.ncbi.nlm.nih.gov/pubmed/15619633

31. Ruijter AJMDE, Gennip AHVAN, Caron HN, Kemp S, Kuilenburg ABPVAN. Histone deacetylases ( HDACs ) : characterization of the classical HDAC family. 2003;749:737-49.

32. Ivanov M, Barragan I, Ingelman-Sundberg M. Epigenetic mechanisms of importance for drug treatment. Trends Pharmacol Sci [Internet]. 2014 Aug;35(8):384-96. Available from:

http://www.ncbi.nlm.nih.gov/pubmed/24993164

33. Nebbioso A, Carafa V, Benedetti R, Altucci L. Trials with "epigenetic" drugs: an update. Mol Oncol [Internet]. 2012 Dec;6(6):657-82. Available from:

http://www.ncbi.nlm.nih.gov/pubmed/23103179

34. Mai A, Altucci L. Epi-drugs to fight cancer: from chemistry to cancer treatment, the road ahead. Int J Biochem Cell Biol [Internet]. 2009 Jan [cited 2015 May 
11];41(1):199-213. Available from:

http://www.ncbi.nlm.nih.gov/pubmed/18790076

35. Wang Y-C, Peterson SE, Loring JF. Protein post-translational modifications and regulation of pluripotency in human stem cells. Cell Res [Internet]. Nature Publishing Group; 2014 Feb [cited 2015 Mar 18];24(2):143-60. Available from: http://www.pubmedcentral.nih.gov/articlerender.fcgi?artid=3915910\&tool=pmce ntrez\&rendertype=abstract

36. Woodcock CL, Ghosh RP. Chromatin higher-order structure and dynamics. Cold Spring Harb Perspect Biol [Internet]. 2010 May;2(5):a000596. Available from:

http://www.pubmedcentral.nih.gov/articlerender.fcgi?artid=2857170\&tool=pmce ntrez\&rendertype $=$ abstract

37. Davey C a, Sargent DF, Luger K, Maeder AW, Richmond TJ. Solvent mediated interactions in the structure of the nucleosome core particle at 1.9 a resolution. J Mol Biol. 2002 Jun 21;319(5):1097-113.

38. Donnell GMC. Antiseptics and Disinfectants : Activity, Action, and Resistance. 1999;12(1):147-79.

39. Mahadev K, Vemuri MC. Ethanol-induced changes in hepatic chromatin and nonhistone nuclear protein composition in the rat. Alcohol [Internet]. 1998 Apr;15(3):207-11. Available from:

http://www.ncbi.nlm.nih.gov/pubmed/9539377

40. Kirpich I, Zhang J, Gobejishvili L, Kharebava G, Barker D, Ghare S, et al. Binge Ethanol-Induced HDAC3 Cpt1a Expression Leading to Hepatic Steatosis and Injury. 2014;(11):1920-9.

41. Smondyrev a M, Berkowitz ML. Structure of dipalmitoylphosphatidylcholine/cholesterol bilayer at low and high cholesterol concentrations: molecular dynamics simulation. Biophys J [Internet]. Elsevier; 1999 Oct [cited 2015 Jun 15];77(4):2075-89. Available from: http://www.pubmedcentral.nih.gov/articlerender.fcgi?artid=1300489\&tool=pmce ntrez\&rendertype $=$ abstract

42. Hanukoglu I. Steroidogenic enzymes: structure, function, and role in regulation of steroid hormone biosynthesis. J Steroid Biochem Mol Biol [Internet]. 1992 Dec;43(8):779-804. Available from:

http://www.ncbi.nlm.nih.gov/pubmed/22217824

43. Olson RE. Symposium : Evolution of Ideas about the Nutritional Value of Dietary Fat Discovery of the Lipoproteins, Their Role in Fat Transport and Their Significance as Risk Factors 1. 1998;439-43.

44. Brown MS, Goldstein JL. The SREBP Pathway: Regulation of Cholesterol Metabolism by Proteolysis of a Membrane-Bound Transcription Factor. Cell 
[Internet]. 1997 May;89(3):331-40. Available from: http://linkinghub.elsevier.com/retrieve/pii/S0092867400802135

45. Yeagle PL, Albert AD, Boesze-battaglia K, Young J, Frye J. Cholesterol dynamics in membranes. 1990;57(March):413-24.

46. Maxfield FR, Wüstner D. Intracellular cholesterol transport. J Clin Invest [Internet]. 2002 Oct 1;110(7):891-8. Available from: http://www.jci.org/articles/view/16500

47. Regenass-klotz M, Heinigek H. Specific binding of cholesterol to chromatin prepared from mouse spleen cells '. 1983;2-3.

48. Albi E, Magni MV. The presence and the role of chromatin cholesterol in rat liver regeneration. J Hepatol [Internet]. 2002 Mar;36(3):395-400. Available from: http://linkinghub.elsevier.com/retrieve/pii/S0168827801003014

49. Lowary PT, Widom J. New DNA sequence rules for high affinity binding to histone octamer and sequence-directed nucleosome positioning. J Mol Biol [Internet]. 1998 Feb 13;276(1):19-42. Available from:

http://www.ncbi.nlm.nih.gov/pubmed/9514715

50. Routh AL. The Determinants of the Structure of the $30 \mathrm{~nm}$ Chromatin Fibre. 2009;(March).

51. Vignali M, Hassan AH, Neely KE, Workman JL. MINIREVIEW ATP-Dependent Chromatin-Remodeling Complexes. 2000;20(6):1899-910.

52. Sarma K, Reinberg D. Histone variants meet their match. Nat Rev Mol Cell Biol [Internet]. $2005 \mathrm{Feb}$ [cited 2014 Mar 21];6(2):139-49. Available from: http://www.ncbi.nlm.nih.gov/pubmed/15688000

53. Da Silva ITG, de Oliveira PSL, Santos GM. Featuring the nucleosome surface as a therapeutic target. Trends Pharmacol Sci [Internet]. Elsevier Ltd; 2015 May [cited 2015 Jul 14];36(5):263-9. Available from: http://www.ncbi.nlm.nih.gov/pubmed/25835595 


\section{ANEXO}

\section{Cálculos}

a) Cálculo da concentração (quantidade de moles) do mononucleossomo usado

Multiplicamos a quantidade de pares de bases pelo número de repetições do arranjo, portanto

$167 \times 1=167 \mathrm{pb}=681,026 \mathrm{Da}=681,026 \mathrm{~g} / \mathrm{mol}$

Considerando que: $1 p b=640 \mathrm{Da}$, então:

$167 \times 1=167 \mathrm{pb}=681,026 \mathrm{Da}$

Considerando que $1 \mathrm{Da}=1 \mathrm{~g} / \mathrm{mol}$

$167 \times 1=167 \mathrm{pb}=681,026 \mathrm{Da}=681,026 \mathrm{~g} / \mathrm{mol}$

Utilizamos $1 \mu \mathrm{g}\left(1.10^{-6} \mathrm{~g}\right)$ de DNA na reconstituição, então:

$$
1.10^{-6}(\mathrm{~g}) \longrightarrow \mathrm{x}(\mathrm{mol}) \rightarrow \mathrm{x}=1,46.10^{-9} \mathrm{~mol}
$$

$681,026 \mathrm{~g}(\mathrm{~g})-1(\mathrm{~mol})$

\section{b) Concentração estoque do etanol usado}

Concentração estoque:17,14M

c) Colesterol

Colesterol $10 \mathrm{x}=4,5 \mathrm{mg} / \mathrm{dL} \rightarrow 0,045 \mathrm{~g} / \mathrm{L}=11,6 \mu \mathrm{M}$ 
